\title{
Phytoplankton diversity in Adriatic ports: Lessons from the port baseline survey for the management of harmful algal species
}

\author{
Patricija Mozetič ${ }^{\mathrm{a}, *, 1}$, Monica Cangini ${ }^{\mathrm{b}, 1}$, Janja Francée ${ }^{\mathrm{a}}$, Mauro Bastianini ${ }^{\mathrm{c}}$, \\ Fabrizio Bernardi Aubryc, Mia Bužančićc ${ }^{\mathrm{d}}$, Marina Cabrini ${ }^{\mathrm{e}}$, Federica Cerino ${ }^{\mathrm{e}}$, Marijeta Čalić ${ }^{\mathrm{f}}$, \\ Raffaele D'Adamo $^{g}$, Dragana Drakulovic ${ }^{h}$, Stefania Finotto ${ }^{c}$, Daniela Fornasaro ${ }^{\mathrm{e}}$, Federica Grilli ${ }^{\mathrm{i}}$, \\ Romina Kraus ${ }^{j}$, Nataša Kužat ${ }^{j}$, Daniela Marić Pfannkuchen ${ }^{j}$, Živana Ninčević Gladan ${ }^{\mathrm{d}}$, \\ Marinella Pompei ${ }^{\mathrm{b}}$, Ana Rotter ${ }^{\mathrm{a}}$, Irene Servadei ${ }^{\mathrm{b}}$, Sanda Skejić ${ }^{\mathrm{d}}$ \\ ${ }^{a}$ National Institute of Biology, Marine Biology Station, Fornače 41, 6330 Piran, Slovenia \\ ${ }^{\mathrm{b}}$ Fondazione Centro Ricerche Marine, National Reference Laboratory on Marine Biotoxins, V.le A. Vespucci 2, 47042 Cesenatico, FC, Italy \\ ${ }^{\mathrm{c}}$ Institute of Marine Sciences, National Research Council, Castello 2737/f, 30122 Venice, Italy \\ d Institute of Oceanography and Fisheries, Šetalište I. Meštrovića 63, 21000 Split, Croatia \\ e Oceanography Division, Istituto Nazionale di Oceanografia e di Geofisica Sperimentale - OGS, via Piccard 54, 34151 Trieste, Italy \\ ${ }^{\mathrm{f}}$ University of Dubrovnik, Institute for Marine and Coastal Research, Kneza Damjana Jude 12, 20000 Dubrovnik, Croatia \\ ${ }^{\mathrm{g}}$ Institute of Marine Sciences, National Research Council, Via Pola 4, 71010 Lesina, FG, Italy \\ ${ }^{\text {h }}$ University of Montenegro, Institute of Marine Biology, Dobrota bb, 85330 Kotor, Montenegro \\ ${ }^{\mathrm{i}}$ Institute of Marine Sciences, National Research Council, Largo Fiera della Pesca 2, 60125 Ancona, Italy \\ ${ }^{\mathbf{j}}$ Ruđer Bošković Institute, Center for Marine Research, Giordano Paliaga 5, 52210 Rovinj, Croatia
}

\section{A R T I C L E I N F O}

\section{Keywords:}

Port baseline survey

Phytoplankton

Harmful algae

Non-indigenous species

Ballast waters

Adriatic Sea

\begin{abstract}
A B S T R A C T
An inventory of phytoplankton diversity in 12 Adriatic ports was performed with the port baseline survey. Particular emphasis was put on the detection of harmful aquatic organisms and pathogens (HAOP) because of their negative impact on ecosystem, human health, and the economy. Phytoplanktonic HAOP are identified as species, either native or non-indigenous (NIS), which can trigger harmful algal blooms (HAB). A list of 691 taxa was prepared, and among them 52 were classified as HAB and five as NIS. Records of toxigenic NIS (Pseudonitzschia multistriata, Ostreopsis species including $O$. cf. ovata) indicate that the intrusion of non-native invasive phytoplankton species has already occurred in some Adriatic ports. The seasonal occurrence and abundance of HAOP offers a solid baseline for a monitoring design in ports in order to prevent ballast water uptake and possible expansion of HAOP outside their native region.
\end{abstract}

\section{Introduction}

In 2004, the International Maritime Organisation (IMO) released the International Convention for the Control and Management of Ship's Ballast Water and Sediments (BWM Convention), which regulates the control of ballast waters, as they may be vectors of dispersion of harmful aquatic organisms and pathogens (HAOP) in the world's oceans and seas. The HAOP includes all potentially harmful non-indigenous species, as well as cryptogenic and impacting native aquatic species including pathogens (David et al., 2013).

Based on the definitions of Pyšek et al. (2009), non-indigenous species (NIS; synonyms: alien, exotic, non-native, allochthonous) are species, subspecies, or lower taxa introduced outside of their natural range (past or present) and outside of their natural dispersal potential. This includes any part, gamete, or propagule of such species that might survive and subsequently reproduce. Invasive alien species (IAS) are a

\footnotetext{
* Corresponding author.

E-mail addresses: patricija.mozetic@nib.si (P. Mozetič), monica.cangini@centroricerchemarine.it (M. Cangini), janja.france@nib.si (J. Francé), mauro.bastianini@ismar.cnr.it (M. Bastianini), fabrizio.bernardi@ismar.cnr.it (F. Bernardi Aubry), buzancic@izor.hr (M. Bužančić), mcabrini@inogs.it (M. Cabrini), fcerino@ogs.trieste.it (F. Cerino), marijeta.calic@unidu.hr (M. Čalić), raffaele.dadamo@fg.ismar.cnr.it (R. D'Adamo), ddragana@t-com.me (D. Drakulović),

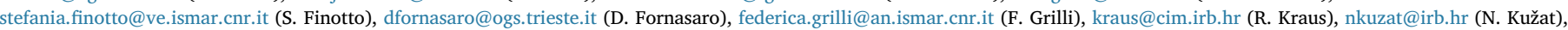
daniela.maric@cim.irb.hr (D. Marić Pfannkuchen), nincevic@izor.hr (Ž. Ninčević Gladan), marinella.pompei@centroricerchemarine.it (M. Pompei), ana.rotter@nib.si (A. Rotter), irene.servadei@centroricerchemarine.it (I. Servadei), sanda@izor.hr (S. Skejić).

${ }^{1}$ These authors contributed equally to the work.
} 
subset of established NIS, which have an adverse effect on biological diversity, ecosystem functioning, socio-economic values, and/or human health in invaded regions. Species of unknown origin, which cannot be ascribed as being native or NIS are, according to Carlton (1996), named cryptogenic. They may also demonstrate invasive characteristics and should be included in IAS assessments (Olenin et al., 2010). In addition to the BMW Convention, the policy management of NIS is also one of the focuses of the EU Marine Strategy Framework Directive (2008/56/ EC) and the EU Regulation on the prevention and management of the introduction and spread of IAS (Regulation (EU) n. 1143/2014).

The Adriatic Sea is a highly sensitive ecosystem. Its preservation and health are crucial for the economic development and social well-being of all neighboring countries. The Adriatic Sea is also an important seaway mainly used by international shipping transporting goods to or from Europe's hinterland, with also busy local shipping (Penko et al., 2016). With such marine traffic, the transfer of HAOP by ships' ballast water is of serious concern. Monitoring programs and surveillance activities would be of limited efficacy if carried out on a local scale. The overall objective of the BALMAS project (Ballast Water Management System for Adriatic Sea Protection) was to establish a common crossborder system in the Adriatic Sea, which would link all researchers, experts, and responsible national authorities in order to avoid unwanted risks to the environment from the transfer of HAOP.

The detection of HAOP in ports includes baseline surveys and follow-up monitoring, which are both highly encouraged by the BWM Convention and IMO Guidelines (Awad et al., 2014). The Port Baseline Surveys (PBS) were conducted in 12 Adriatic ports in Italy, Slovenia, Croatia, Montenegro, and Albania in order to get a broader picture of the biota present in the survey area. Furthermore, PBS provided information about the presence and possible negative effects of HAOP, either native or NIS, in ports and surrounding areas, as hotspots of ballast waters discharge and uptake.

A lively discussion has been raised by the scientific community on which criteria should be applied to classify organisms as HAOP in the context of the Early Warning System to ships. While the criteria for the selection of pathogens and their warning abundance levels are quite clear, it was necessary to narrow down the broader category of harmful aquatic organisms (Garaventa et al., 2014) from unicellular eukaryotic organisms to plants and animals. In case of phytoplankton and microalgae in general, HAOP are considered all those species that form Harmful Algal Blooms (HAB). HAB species comprise toxic and harmful species that are associated with human poisoning, mortalities of marine organisms, or significant changes in marine ecosystems (Lassus et al., 2016). HAB species can be either native or non-indigenous, but in the context of harmful impacts, their origin is irrelevant. Nevertheless, phytoplankton NIS and cryptogenic species with as yet unknown invasive potential should be tightly monitored in order to understand their biological characteristics and behavior in the new environment.

Phytoplankton communities of the Adriatic Sea present highly diverse characteristics. In the shallow northern Adriatic sub-basin the main freshwater source, the Po River, drives a marked west to east gradient of physical and biological properties (Bernardi Aubry et al., 2012; Kraus and Supić, 2011). The freshwater-driven hydrology also causes a pronounced spatial variability of phytoplankton abundance and biomass along the western coastal waters of the Adriatic Sea (Mangoni et al., 2008), while the eastern coastal waters are under the influence of highly saline, oligotrophic waters advected by the Eastern Adriatic Current (Artegiani et al., 1997a).

There is extensive literature concerning phytoplankton distribution and its dynamics in the northern Adriatic (e.g., Bernardi Aubry et al., 2004; Cabrini et al., 2012; Godrijan et al., 2013; Kraus et al., 2016; Marić et al., 2012; Mozetič et al., 2012; Socal et al., 2002; Viličić et al., 2009), whereas fewer studies can be found for the central (Bužančić et al., 2016; Ninčević Gladan et al., 2010a) and southern Adriatic (Campanelli et al., 2013; Caroppo et al., 1999a; Drakulović et al., 2017;
Moscatello et al., 2011; Saracino and Rubino, 2006). Among this rich collection of phytoplankton literature, there is also lots of research about HAB species and events recently reviewed by Pistocchi et al. (2012) and Arapov et al. (2015). Over the past 20 years, seafood contamination has been predominantly associated with lipophilic toxins (Ninčević Gladan et al., 2011; Ninčević Gladan et al., 2008). Rigorous monitoring and focused research have led to the detection of new marine toxins and/or producing species, also emerging elsewhere in world oceans (Lassus et al., 2016). Among these Azadinium, Ostreopsis and Karenia species deserve special attention due to their toxin producing potential for azaspiracids, palytoxins, and brevetoxins, respectively (Bacchiocchi et al., 2015; Gallitelli, 2005; Pfannkuchen et al., 2012). Recurrent blooms of potentially ichthyotoxic raphidophytes are also recorded, however without fish mortalities so far (Pistocchi et al., 2012).

The increased number of toxic species and harmful events could be a consequence of global warming that may provoke alterations in the dynamics of marine microorganisms. A number of studies show that the biodiversity of the Mediterranean Sea is undergoing rapid alteration, but most of these studies correspond to macroscopic organisms and little is known about the changes of phytoplankton communities (Gómez, 2010).

Given that some habitats, such as lagoons and ports, act as "hubs" of introduction of NIS (Corriero et al., 2016), it is necessary to have a broader picture of the current situation around the Adriatic ports. This will enable the tracking of changes in phytoplankton communities, as well as the detection of changes in HAB and NIS dynamics.

The specific objectives of this study were:

- To create a reference list of phytoplankton species in Adriatic ports and to draw general community patterns,

- To develop a catalogue of HAB species, along with their biological, ecological, and toxigenic characteristics, which are necessary information for monitoring plans and early warning systems,

- To develop a catalogue of non-indigenous and cryptogenic species which will set grounds for studying their spread and harmful potential.

\section{Materials and methods}

\subsection{Sampling area and scheme}

Sampling for the PBS was carried out in 12 Adriatic ports (Fig. 1) in 2014 and 2015. The exceptions are field campaigns in the ports of Split and Ploče, which were conducted in 2011, before the project BALMAS was launched, as part of the Croatian National port baseline survey project.

In all PBS samplings the same design (selection of sites, frequency of sampling, parameters, and methods) was adopted. We summarised the most important information on sampling scheme for phytoplankton analyses in 12 ports (Table 1). The sampling frequency was designed to cover all four seasons. The full seasonal coverage was accomplished in six ports. In five ports it still met the requirement of the PBS Protocol, i.e. three to four samplings per year, while in the port of Durres only two seasons were sampled. In order to increase the time coverage and consequently to enlarge the data set with identified taxa we present the results of the additional monitoring campaigns. These samplings were performed in six out of 12 ports once or twice during the duration of the project following the same sampling scheme adopted in PBS campaigns.

Several environmental parameters (temperature, salinity, oxygen, nutrients, transparency, etc.) were measured; however, for the sake of this paper we report on only temperature and salinity, which are also mandatory by the PBS Protocol. Temperature and salinity were recorded either along the water column using fine-scale CTD probes, or on the surface with a portable conductivity meter. 


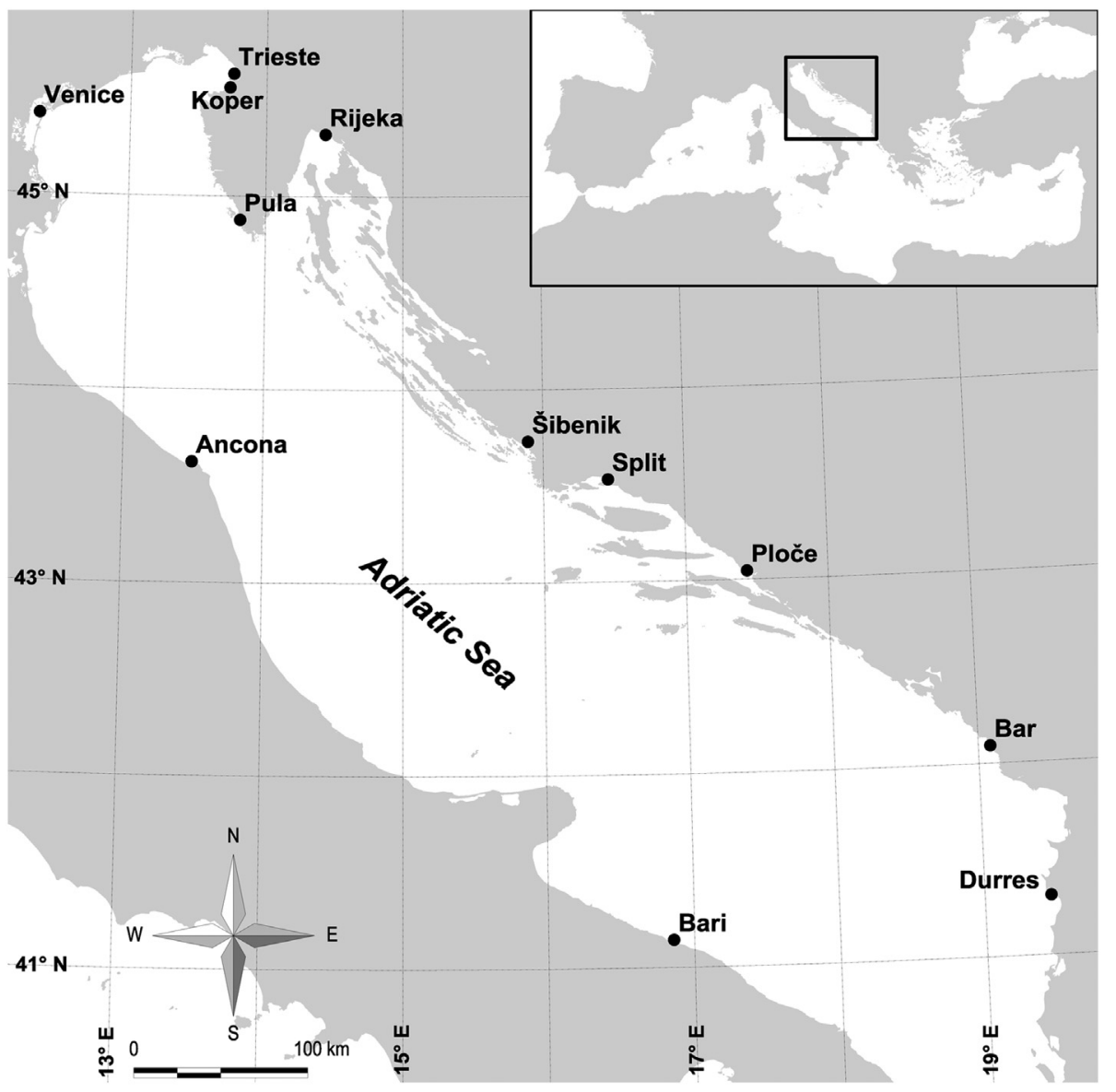

Fig. 1. Map of the Adriatic Sea with locations of 12 ports where sampling campaigns of the Port Baseline Survey (PBS) for phytoplankton were conducted.

Phytoplankton was sampled both for quantitative and qualitative analyses at each station. For qualitative analyses microphytoplankton (20-200 $\mu \mathrm{m}$; hereinafter referred to as phytoplankton) was collected by one to two vertical tows using a phytoplankton net with mesh size of $20 \mu \mathrm{m}$. In accordance to the PBS Protocol, horizontal net samples were collected at selected stations as well. Horizontal tows were taken at a depth of approx. $2 \mathrm{~m}$ and at speed of approx. $0.30 \mathrm{~m} \mathrm{~s}^{-1}$ along transects of 20 to $120 \mathrm{~m}$.

For quantitative analyses and to ensure an accurate analysis of smaller $(<20 \mu \mathrm{m})$ phytoplankton species, which were discarded in net samples, water samples were collected as well. These samples were taken either at discrete depths using Niskin bottles or buckets, or as integrated water column samples collected by a hose-sampler accommodated to different depths of sampling stations (Sutherland et al., 1992). When Niskin bottles were used, water was collected at different sampling depths; however, surface layer was always sampled. In two ports, water samples were filtered through $300 \mu \mathrm{m}$ plankton net immediately after collection.

Net and water samples were fixed with neutralised formaldehyde (final concentration range $<1$ to $4 \%$ ) or Lugol's solution and stored in a dark and cool place until analysis (Throndsen, 1978). In some cases (ports of Ancona and Bari) live material was also observed. Detail information on sampling scheme and analysis of samples carried out in each port and by each laboratory are presented in Table 2 .

\subsection{Microscopic analysis}

Phytoplankton was examined on inverted microscopes equipped with digital cameras. Dinoflagellates were occasionally examined for thecal plates arrangement using the staining technique with Calcofluor White MR2 (Fritz and Triemer, 1985).
Water samples were used to determine the exact abundance of phytoplankton species following the standard quantitative Utermöhl method (Utermöhl, 1958). Depending on cell concentrations, a variable volume of seawater (from 5 to $100 \mathrm{ml}$ ) was settled for an appropriate sedimentation time (from 3 to $72 \mathrm{~h}$ ). The organisms found in the sedimentation chamber were then identified and counted taking into account the size and abundance of species (Zingone et al., 2010). In the cases of larger and rare species, the whole or half of the bottom chamber was checked at $100 \times$ or $200 \times$ magnification. Smaller or particularly abundant species were counted along several transects, or only in a smaller number of fields under higher magnifications (from $200 \times$ to $630 \times$, although $400 \times$ was the preferable magnification).

Net samples were used for both qualitative and semi-quantitative analysis. A few millilitres (0.5-2.5 ml) of each well-mixed sample were poured directly into the sedimentation chamber and allowed to settle for at least $2 \mathrm{~h}$. The whole chamber bottom or several transects of the bottom chamber were examined at lower magnification (in general at $200 \times$ ). An arbitrary semi-quantitative abundance score in a scale from 1 to 5 was assigned to every taxon found, where 1 stands for rare and 5 for prevailing taxon.

Identification of specimens was done to the lowest possible taxonomic level (species, genus) making use of numerous identification keys. Species names were checked for validity against AlgaeBase (Guiry and Guiry, 2017) and relevant recent publications. Authors of species names were reviewed according to the International Plant Name Index (http://www.ipni.org/ipni/authorsearchpage.do). The list also includes heterotrophic species of certain dinoflagellate and nanoflagellate genera, and of the protozoan class Cercozoa, which are usually analysed by phytoplanktologists. Benthic and freshwater taxa are included as well, inferring physical and hydrological characteristics of water bodies such as ports. 
Table 1

List of the 12 Adriatic ports and basic information regarding sampling activities within the Port Baseline Survey for phytoplankton.

\begin{tabular}{|c|c|c|c|c|}
\hline Port & Abbreviation & Country & Sampling date & No. sampling stations \\
\hline \multirow[t]{11}{*}{ Ancona } & AN & Italy & 08.05.2014 & 2 \\
\hline & & & 24.05 .2014 & 4 \\
\hline & & & 22.08 .2014 & 4 \\
\hline & & & 24.08 .2014 & 4 \\
\hline & & & 27.08.2014 & 2 \\
\hline & & & 27.10 .2014 & 2 \\
\hline & & & 29.10 .2014 & 4 \\
\hline & & & 13.02.2015 & 4 \\
\hline & & & 17.02.2015 & 2 \\
\hline & & & 06.05 .2015 & 4 \\
\hline & & & 21.05 .2015 & 2 \\
\hline \multirow[t]{7}{*}{ Bari } & $\mathrm{BI}$ & Italy & 26.05 .2014 & 6 \\
\hline & & & 05.08 .2014 & 3 \\
\hline & & & 10.09 .2014 & 3 \\
\hline & & & 04.11 .2014 & 3 \\
\hline & & & 05.11 .2014 & 3 \\
\hline & & & 04.03 .2015 & 3 \\
\hline & & & 12.05 .2015 & 6 \\
\hline \multirow[t]{4}{*}{ Bar } & BA & Montenegro & 11.02 .2015 & 4 \\
\hline & & & 15.04 .2015 & 4 \\
\hline & & & 23.06 .2015 & 4 \\
\hline & & & 26.10 .2015 & 4 \\
\hline \multirow[t]{2}{*}{ Durres } & DU & Albania & 06.06 .2014 & 3 \\
\hline & & & 06.11 .2014 & 4 \\
\hline \multirow[t]{5}{*}{ Koper } & КО & Slovenia & 09.05 .2014 & 5 \\
\hline & & & 28.07 .2014 & 5 \\
\hline & & & 17.11 .2014 & 5 \\
\hline & & & 09.02 .2015 & 5 \\
\hline & & & 16.09 .2015 & 4 \\
\hline \multirow[t]{4}{*}{ Ploče } & PL & Croatia & 13.05 .2011 & 4 \\
\hline & & & 14.05 .2011 & 1 \\
\hline & & & 21.07 .2011 & 3 \\
\hline & & & 11.10 .2011 & 4 \\
\hline \multirow[t]{6}{*}{ Pula } & PU & Croatia & 09.09 .2014 & 4 \\
\hline & & & 18.12 .2014 & 4 \\
\hline & & & 11.02 .2015 & 4 \\
\hline & & & 06.05 .2015 & 4 \\
\hline & & & 16.07 .2015 & 4 \\
\hline & & & 09.11 .2015 & 4 \\
\hline \multirow[t]{11}{*}{ Rijeka } & RI & Croatia & 10.09 .2014 & 1 \\
\hline & & & 11.09 .2014 & 3 \\
\hline & & & 19.12 .2014 & 1 \\
\hline & & & 20.12 .2014 & 3 \\
\hline & & & 12.02 .2015 & 1 \\
\hline & & & 13.02 .2015 & 3 \\
\hline & & & 23.04 .2015 & 1 \\
\hline & & & 24.04 .2015 & 3 \\
\hline & & & 14.07.2015 & 4 \\
\hline & & & 10.11 .2015 & 1 \\
\hline & & & 11.11 .2015 & 3 \\
\hline \multirow[t]{5}{*}{ Split } & ST & Croatia & 28.04 .2011 & 4 \\
\hline & & & 12.07 .2011 & 4 \\
\hline & & & 05.10 .2011 & 4 \\
\hline & & & 23.04 .2014 & 4 \\
\hline & & & 24.08 .2014 & 4 \\
\hline Šibenik & SI & Croatia & 18.12 .2013 & 3 \\
\hline & & & 24.04 .2014 & 3 \\
\hline & & & 26.08 .2014 & 3 \\
\hline & & & 12.12 .2014 & 3 \\
\hline Trieste & TS & Italy & 12.05 .2014 & 7 \\
\hline & & & 30.06 .2014 & 7 \\
\hline & & & 23.09 .2014 & 7 \\
\hline & & & 27.01.2015 & 7 \\
\hline & & & 15.07 .2015 & 7 \\
\hline Venice & $\mathrm{VE}$ & Italy & 25.03 .2014 & 6 \\
\hline & & & 26.03 .2014 & 1 \\
\hline & & & 20.05 .2014 & 5 \\
\hline & & & 21.05 .2014 & 1 \\
\hline & & & 08.08 .2014 & 3 \\
\hline & & & 27.08 .2014 & 1 \\
\hline & & & 21.10 .2014 & 3 \\
\hline & & & 22.10 .2014 & 4 \\
\hline & & & 11.02 .2015 & 7 \\
\hline & & & 17.05 .2015 & 1 \\
\hline & & & 27.05 .2015 & 6 \\
\hline
\end{tabular}

\subsection{Selection of HAOP (HAB, NIS, cryptogenic) in phytoplankton communities}

HAOP in the phytoplankton communities of 12 Adriatic ports comprised harmful and potentially harmful algal bloom species (HAB), non-indigenous (NIS), and cryptogenic species. For the sake of simplicity we refer to harmful and potentially harmful species as harmful only (i.e., $\mathrm{HAB}$ ) from here on. HAB species were determined according to the IOC-UNESCO Taxonomic Reference List of Toxic Microalgae (Moestrup et al., 2009 onwards) and the most recent review of HABs of the world ocean (Lassus et al., 2016). This monograph is based on the IOC-UNESCO taxonomic list, which authors updated with all available data from international scientific literature, expert panel reports (e.g. ICES report of the ICES-IOC WGHABD, http://www.ices.dk/sites/pub/), technical reports, internet articles, and any kind of gray literature. Some exceptions were made for taxa, which are not reported by these lists and will be explained case-by-case later in the Results and Discussion sections. Species for which documentation for toxicity is lacking, or their harmful impact is uncertain were also annotated.

Conferring the status of NIS was done against extensive scientific literature on NIS in the Mediterranean Sea (e.g. Blanco and Ector, 2009; Corriero et al., 2016; Gómez, 2008; Streftaris and Zenetos, 2006; Streftaris et al., 2005; Zingone, 2015), and was compared with online information systems such as AquaNIS (Editorial Board, 2015) and EASIN (https://easin.jrc.ec.europa.eu/). We started from the work of Gómez (2008), who critically reviewed the categorisation done by Streftaris et al. (2005) of 15 phytoplankton species as NIS for the Mediterranean Sea. The review of Gómez (2008) was then compared with recent assessments of alien and invasive species along Italian coastal waters (Corriero et al., 2016; Zingone, 2015). Species were classified as cryptogenic when not reported by broad literature on phytoplankton diversity of the Mediterranean Sea (e.g. Gómez, 2003) and its marginal seas (mainly Cabrini et al., 2010a; Cabrini et al., 2010b; Caroppo, 2010; Rampi and Bernhard, 1980; Viličić et al., 2002).

\subsection{Data analysis}

Data analysis was limited to species and genera only, whereas unidentified categories higher than genus (e.g. unidentified Bacillariophyta) were not considered in any of analyses or graphic presentation. Abiotic and phytoplankton data were aggregated in the four meteorological seasons: spring (March-May), summer (June-August), autumn (September-November), and winter (December-February).

Since net samples were taken in all ports, which was not the case of water samples (see Table 2), further analyses of the phytoplankton community structure were done on net samples and relative abundances. In case a taxon was found in several stations of the same port in one season, we considered only the entry, i.e. sampling station, with the highest abundance score. This step was necessary in order to simplify the complexity of the data (in total 15,519 entries), but to still keep all important information. Such transformed data were then used in the social network analysis (SNA) to discover characteristic seasonal patterns of the Adriatic phytoplankton community and similarities between Adriatic ports.

Assessment for the presence/absence of HAOP (HAB, NIS, and cryptogenic species) was done on the whole set of data regardless of the type of the sample, i.e. net or water sample. Thorough analyses were then performed on HAB species, as they represent the core of HAOP. Net samples were used in the same network analysis (SNA) as for the whole phytoplankton community in order to discern the most important HAB species as regard their frequency, relative abundance, and spatial distribution. These species were afterward examined more in detail using their absolute abundance (cells $1^{-1}$ ) determined in water samples. Prior to run SNA, the reduction of entries of HAB species in net and water samples was done in the same way as described above for the 
Table 2

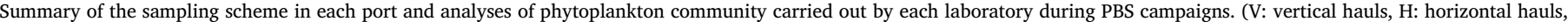
integr. w. c.: integrated water column).

\begin{tabular}{|c|c|c|c|c|c|c|}
\hline Port & Laboratory & Net sample & Water sample & No. sampling depths & Relative abundance (1-5) & Absolute abundance (cell $1^{-1}$ ) \\
\hline Ancona & MRCF & $\mathrm{V}, \mathrm{H}$ & Bottle & $1(0 \mathrm{~m})$ & $\mathrm{x}$ & $\mathrm{x}$ \\
\hline Bari & MRCF & $\mathrm{V}, \mathrm{H}$ & Bottle & $1(0 \mathrm{~m})$ & $\mathrm{x}$ & $\mathrm{x}$ \\
\hline Bar & UoM-IMB & $\mathrm{V}, \mathrm{H}$ & Bottle & $3(0 \mathrm{~m})$ & $\mathrm{x}$ & $\mathrm{x}$ \\
\hline Durres & UD & $\mathrm{V}$ & Bottle & $3(0 \mathrm{~m})$ & $\mathrm{x}$ & $\mathrm{x}$ \\
\hline Koper & NIB-MBS & $\mathrm{V}, \mathrm{H}$ & Hose & Integr. w. c. & $\mathrm{x}$ & $\mathrm{x}^{\mathrm{a}}$ \\
\hline Ploče & UD & $\mathrm{V}, \mathrm{H}$ & - & - & $\mathrm{x}$ & - \\
\hline Pula & RBI-CMR & $\mathrm{V}, \mathrm{H}$ & Bottle & $2-4(0 \mathrm{~m})$ & $\mathrm{x}$ & $\mathrm{x}$ \\
\hline Rijeka & RBI-CMR & $\mathrm{V}, \mathrm{H}$ & Bottle & $2-5(0 \mathrm{~m})$ & $\mathrm{x}$ & $\mathrm{x}$ \\
\hline Split & IOR & $\mathrm{V}$ & Bottle & $2-4(0 \mathrm{~m})$ & $\mathrm{x}$ & $\mathrm{x}$ \\
\hline Šibenik & IOR & $\mathrm{V}$ & Bottle & $3-5(0 \mathrm{~m})$ & $\mathrm{x}$ & $\mathrm{x}$ \\
\hline Trieste & OGS & $\mathrm{V}, \mathrm{H}$ & Bottle & $2(0 \mathrm{~m})$ & $\mathrm{x}$ & $\mathrm{x}$ \\
\hline Venice & CNR-ISMAR & $\mathrm{V}$ & Bottle & $1(0 \mathrm{~m})$ & $\mathrm{x}$ & $\mathrm{x}$ \\
\hline
\end{tabular}

a Only HAB species were counted.

whole phytoplankton community.

In this work, SNA was used on two datasets: the whole phytoplankton community and $\mathrm{HAB}$ species only. Multivariate analyses usually applied in ecological studies such as PCA were not done on these data, as the general aim was not to reduce data dimensionality but to uncover the relations between Adriatic ports and species sampled therein. Specifically, a two-mode network analysis was applied where one set of units was represented by ports and the other by species. A species and a port are connected if the species was found in that port. The line values were determined by the relative abundance of the species. The two-mode network was transformed into an ordinary network. This was done in order to: (i) uncover the most important species in each season (i.e. species that were found in higher abundance and in more ports in each season), and to (ii) determine the ports, which were more similar in terms of the number of same species found in those ports and their abundance. First, we searched for connections between species (i.e. two species were connected in case they were found together in at least one port). The value of lines was multiplied by the abundance of the species (abundance categories being 1-5). In the second ordinary network, we assessed the relations between ports (i.e. two ports were connected in case at least one species was found in both ports). The first dataset (all species) was divided into four subsets, with each subset representing one season. The second dataset (HAB species) was not divided according to season.

The most important part of the network, i.e. the part with the strongest potential in network relations, was then selected using the concept of m-slices. These m-slices determine a subnetwork by containing the lines with value equal to or greater than the specified threshold (de Nooy et al., 2011). The threshold was defined after examining the line values (see previous paragraph for an explanation on their definition). These subnetworks represent species and ports with a high informative value for the Adriatic ports, as the species were more commonly found and were more abundant in two or more ports. The predefined threshold was different for each season because a different number of species and their abundances were observed in each season, making it impossible to determine a unified threshold value.

All data analysis and visualisations were done using Pajek software (Batagelj and Mrvar, 2004).

\section{Results}

\subsection{Environmental characteristics of waters in Adriatic ports}

The environmental characteristics of seawater are indicated by basic properties such as surface salinity and temperature, which were measured in all Adriatic ports. Temperatures ranged from 6.1 to $29.1{ }^{\circ} \mathrm{C}$, and the salinity from 4.4 to 38.2 . Data aggregated in meteorological seasons in general show a seasonal distribution of the two parameters typical for coastal waters (Fig. 2). However, salinities < 15 measured in ports of Ploče and Šibenik indicate a deviation from a typical marine environment. An important freshwater influence in these ports was especially pronounced in winter (salinity between 4 and 5 in Šibenik) and spring (salinity as low as 9 and 14 in Ploče and Šibenik, respectively). Sporadic events of low salinities were observed also in ports of Koper (23 and 25 in autumn and spring, respectively), Rijeka (24 in winter), and Venice (24.6 in spring); all salinities $\leq 25$ measured in specific ports are indicated in Fig. 2.

The variability of surface temperature within seasons was smaller than in the case of salinity. Still, the greatest was during spring $\left(12.2-27.6{ }^{\circ} \mathrm{C}\right)$ and autumn $\left(12.9-28.3{ }^{\circ} \mathrm{C}\right)$ as evident from the scattered distribution of data along the $\mathrm{x}$ axis, while winter $\left(6.1-15.6^{\circ} \mathrm{C}\right)$ and summer $\left(19-29.1{ }^{\circ} \mathrm{C}\right)$ data were more aggregated on opposite sides of the $\mathrm{x}$ axis (Fig. 2). The warmest waters of each season were characteristic for the port of Venice and the coldest for the port of Rijeka, except for winter months. Then, the coldest were the highly diluted waters of port of Šibenik, and the port of Venice (on average $8.3^{\circ} \mathrm{C}$ ).

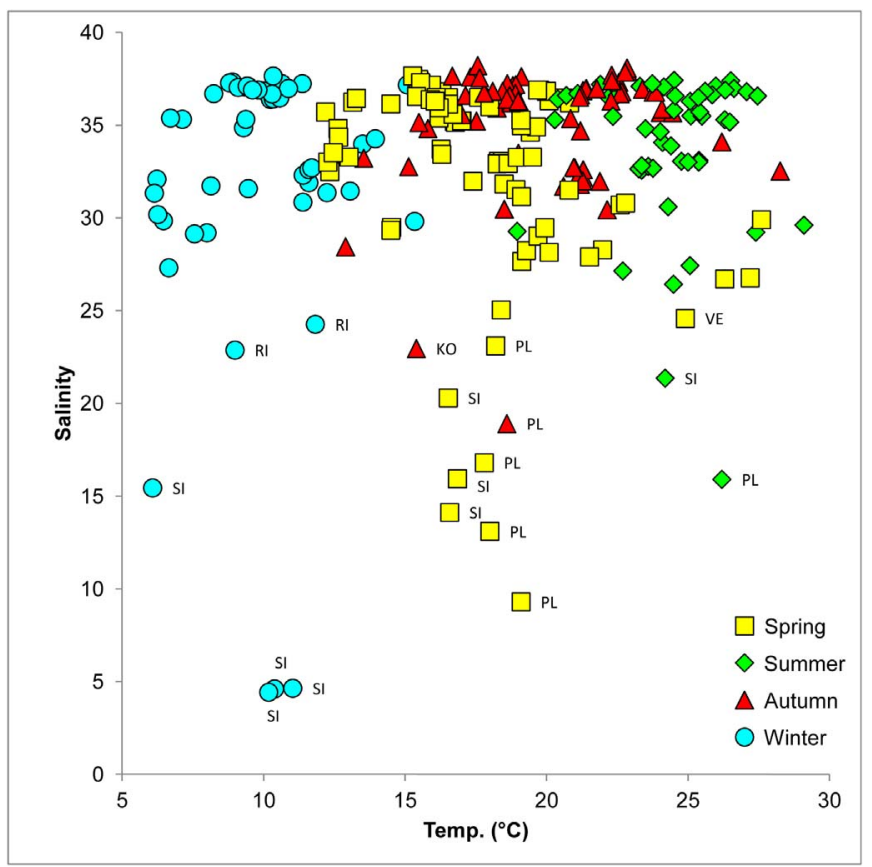

Fig. 2. Surface temperature and salinity recorded in 12 Adriatic ports during the activities of PBS. Data of all dates and sampling stations are seasonally aggregated. Ports with salinity $\leq 25$ are indicated. (KO: Koper, PL: Ploče, RI: Rijeka, SI: Šibenik, VE: Venice). 


\subsection{Phytoplankton diversity and typical communities of Adriatic ports}

Based on the qualitative analyses of net and water samples, the reference list of phytoplankton taxa of Adriatic ports was constructed (Table S1). Benthic and freshwater taxa were also found in some samples, which is inevitably encountered in shallow waters and brackish environments, respectively. The list comprised 691 entries belonging to 13 higher algal taxa (phylum and class): 330 diatoms (Bacillariophyta), 276 dinoflagellates (Dinophyceae), 27 haptophytes (Haptophyta; 24 coccolithophorids and three Prymnesiales), 21 chlorophytes (Chlorophyta), 10 silicoflagellates (Dictyochophyceae), six euglenophytes (Euglenophyta), and six cyanobacteria (Cyanobacteria), four chrysophytes (Chrysophyceae), three cryptophytes (Cryptophyta), two raphidophytes (Raphidophyceae), two xanthophytes (Xanthophyceae), one charophyte (Charophyta), and one Katablepharidophyta. Besides, three species of zooflagellates (phylum Cercozoa) were included in the list and among dinoflagellates, species of the parasitic genus Dissodinium were recorded. Diatoms and dinoflagellates together represented the great majority of all taxa (88\%) in comparison to the remaining 86 taxa (12\%). Ports with the highest species richness were Venice (311 taxa) and Bari (292 taxa), followed by Rijeka (264 taxa), Pula (255 taxa), Ancona (252 taxa), and Split (214 taxa). The lowest number of taxa were found in ports of Durres (104 taxa) and Bar (157 taxa). In the remaining ports species richness was between 170 and 200 taxa. In the majority of ports (7 out of 12), diatoms were the group of the highest species richness, especially in Venice, Durres, and Ploče. In contrast, in the ports of Ancona and Bari the richness of dinoflagellates highly outnumbered that of diatoms, representing $62 \%$ and $57 \%$ of all taxa, respectively. The other two groups that were also found in all ports were haptophytes with prevailing coccolithophorids and silicoflagellates. Differences in diversity were also observed at higher taxonomic levels.

Apart from making the inventory of species in ports, we applied the network analysis on seasonally aggregated data of net samples to construct four seasonal patterns of phytoplankton communities, and to distinguish ports that share similar seasonal outline of the most important species (Fig. 3). Species and genera plotted on networks are written out in full in Table 3. The initial seasonal networks of a minimum 338 taxa in winter and a maximum 513 taxa in spring were reorganised in a way to truly represent the most important taxa of each season (Fig. 3, left panel). These 10 to 13 taxa were found in more than one port in a given season and were in high abundance, which is illustrated by the number of connections between taxa and thickness of lines. The same is true for organisation of ports: a group of ports, which are connected, exhibits greater similarity than the group of unconnected ports (Fig. 3, right panel). Here, the degree of similarity between ports both in term of species composition and abundances is illustrated by their distance on the graph and thickness of connecting lines.

The dominant taxonomic group of all seasons were diatoms and the core of the typical phytoplankton communities was composed of Pseudo-nitzschia spp., Chaetoceros spp., and Thalassionema nitzschioides; yet Pseudo-nitzschia ssp. was the most important in autumn and winter, while Chaetoceros spp. in spring and summer. Species like Cerataulina pelagica, Guinardia flaccida, Leptocylindrus danicus, and Proboscia alata were frequently observed as well (in three out of four seasons). An important contribution of dinoflagellates was exhibited in summer and even more in spring, with Tripos furca and Tripos fusus being characteristic in both periods. Species that really made seasonal differences were Cylindrotheca closterium, Dinophysis sacculus, Prorocentrum micans, and Tripos muelleri in spring, and Prorocentrum compressum and Hermesinum adriaticum in summer. This ebridian heterotrophic flagellate was found in high abundance in ports of Ancona, Koper, and Trieste. Autumn was the only season dominated by one taxonomic group - diatoms and the distinct species of this season were Chaetoceros curvisetus, Guinardia striata, and Lioloma pacificum. Winter was peculiar in several ways: not only was the species richness the lowest and the highest abundance scores ( 4 and 5 ) were assigned in the least number of cases, but it was also the only network where two clusters of characteristic taxa formed. Moreover, 7 out of 12 taxa were exclusive of that period. Besides diatoms such as: Chaetoceros affinis, Ditylum brightwellii, Skeletonema marinoi, Skeletonema spp., and Thalassiosira gravida, a silicoflagellate (Dictyocha fibula) and a haptophyte (Chrysochromulina spp.) which bloomed in the port of Šibenik shaped a characteristic winter community.

The network analysis also demonstrated different levels of seasonally specific similarity between ports based on phytoplankton community structure (Fig. 3, right panel). In all seasons but winter the ports of Ancona and Bari exhibited a high level of similarity. Besides that, in the spring-summer period the middle Adriatic ports of both western (Ancona, Bari) and eastern (Split) coasts, together with the northern Adriatic ports (Venice, Trieste), were more connected than the rest of the ports. The characteristic autumn community was, in contrast, to a great extent shared again by Ancona and Bari and the eastern Adriatic ports at the northern (Pula, Rijeka) and southern (Bar) parts of the basin. The connection between Pula and Rijeka was even more accentuated during winter, sharing the winter community pattern with Venice, Šibenik, and Bar. Interestingly, ports in the northernmost (Koper, and except for the summer, also Trieste) and southernmost (Durres) parts of the Adriatic were always excluded from the subnetwork of greater similarity.

\subsection{HAOP in Adriatic ports (HAB, NIS, cryptogenic)}

The list of HAB species found during PBS surveys in Adriatic ports in net and water samples comprised 52 taxa (Table 4). There are also a few taxa, which are not reported on the IOC-UNESCO taxonomic list and/or Lassus et al. (2016), but due to poor discrimination power down to the species level and the potentially high toxicity they were considered as harmful. That is why unidentified species of genera Pseudo-nitzschia, Alexandrium, Dinophysis, Karenia, Ostreopsis, but also Azadinium and Chrysochromulina, whose harmful effects are uncertain were included in the list.

The richness of HAB species was the greatest among dinoflagellates (35 taxa), followed by diatoms (13 taxa), silicoflagellates ( 2 taxa), and haptophytes and raphidophytes with one taxon each. Dinophysis and Pseudo-nitzschia were the richest genera. More than $10 \%$ of all taxa were benthic - six dinoflagellates (Coolia, Ostreopsis and Prorocentrum species) and one diatom (Halamphora cf. coffeiformis). Table 4 also reports information important for monitoring planning such as the harmful effects and possible formation of resting stages of HAB species. The most frequent harmful effect of HAB species in Adriatic ports is related to the potential production of different toxins that accumulate in seafood. However, fish killings and high biomass blooms with harmful consequences are also likely to occur.

The same network analysis, as in the case of all species, was also applied on HAB species, but the data were not split into seasons. The analysis revealed that the most representative pattern of Adriatic HAB species consisted of nine taxa (Fig. 4, left panel). Pseudo-nitzschia spp. was positioned centrally and formed connections with all other species and with itself (marked by the loop), indicating the highest spatial (ports) and temporal (seasons) coverage and abundance. Gonyaulax polygramma behave similarly to Pseudo-nitzschia spp. Different patterns of occurrence were observed with pairs consisting of Dinophysis caudata and Phalacroma rotundatum, and of Lingulodinium polyedra and Dinophysis sacculus, respectively. Yet another group consisted of Alexandrium spp., Dinophysis fortii, and Gonyaulax spinifera, which had the least similar pattern of occurrence compared to other species. Six ports formed a group of very similar HAB communities (Fig. 4, right panel). Among them, the ports of Split and Ancona expressed the highest level of similarity, while Bar was also close to both. The Port of Ancona 


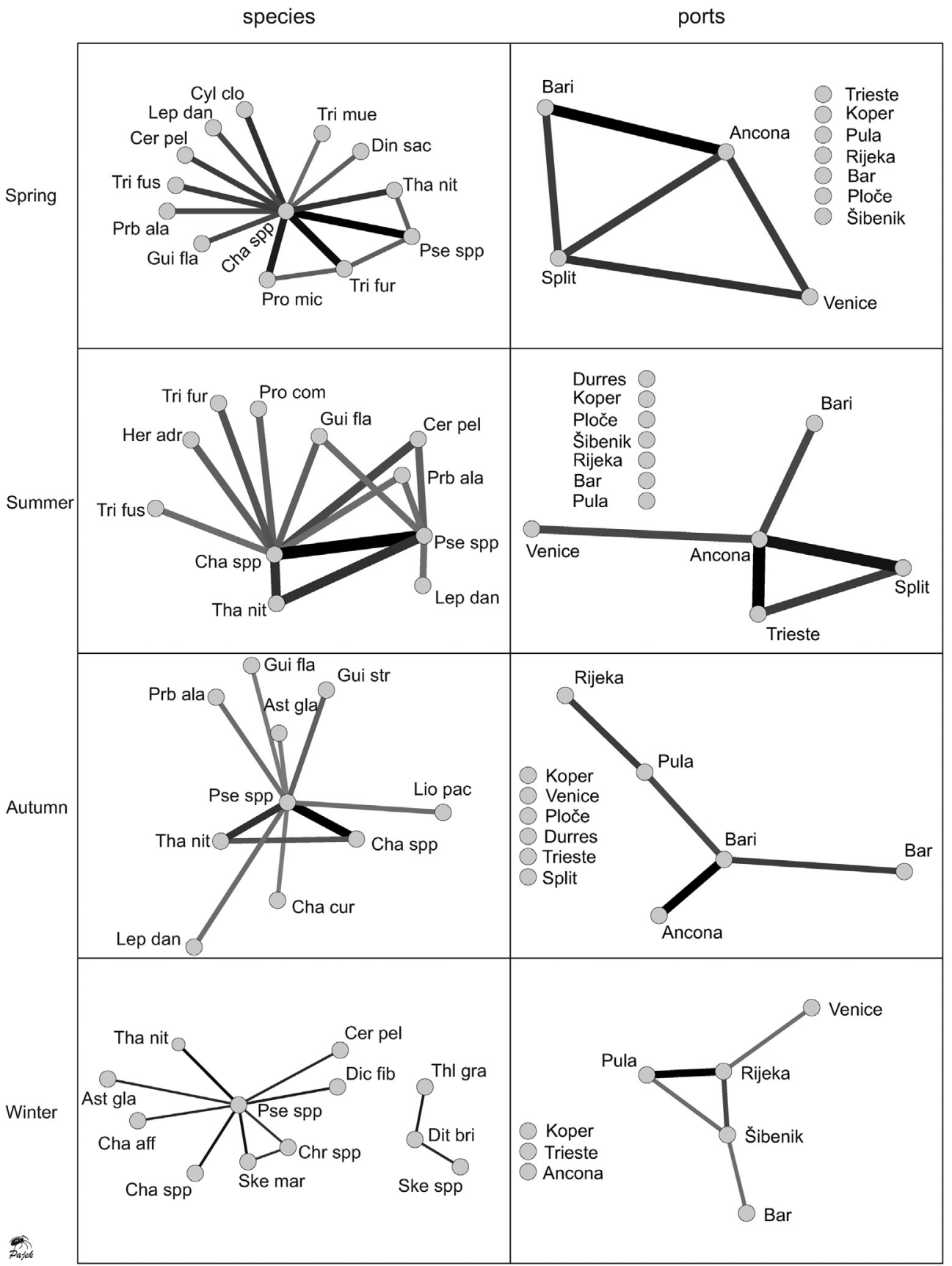

Fig. 3. Network analysis of the whole phytoplankton community. Left panel: four characteristic seasonal patterns, i.e. subnetworks, showing the most important species (by spatial occurrence in ports and relative abundance) found in net samples during PBS campaigns in Adriatic ports. Right panel: connections between similar ports based on the number of same species and their relative abundance in two or more ports. Ports that are more similar are depicted closer. The weight of connecting lines between two species/ ports is denoted by the thickness and depicted with a gray scale. Species codes and respective names are listed in Table 3. connected with two western Adriatic ports (Bari and Venice), whereas Split connected with the closest neighboring port in Šibenik. The remaining ports with more differing $\mathrm{HAB}$ community structures than the connected ports are all located on the eastern coast of the Adriatic. With the exception of the port of Ploče, these ports are the farthest from the "core connection Ancona - Split," namely Durres on the south and Rijeka, Pula, Koper, and Trieste on the north.

Seasonal distribution of the most important HAB species, which resulted from the above analysis, is presented in Fig. 5. Water samples of all ports but Ploče were analysed for the exact abundance of species (cells $1^{-1}$ ). DSP (Diarrhetic Shellfish Poisoning) toxins producing species in general peaked during spring (D. sacculus), autumn (D. fortii), or the autumn and spring period (D. caudata), while $P$. rotundatum was found in high abundance throughout all seasons. Maximal abundance $\left(<500\right.$ cells $1^{-1}$ ) were registered either in Pula or in Rijeka, with the exception of $D$. sacculus, which bloomed in Split (3200 cells $\left.1^{-1}\right)$. These species were always present in the northeastern Adriatic ports (from Trieste to Rijeka), as well as in Ancona, Bari, and Bar. Likewise P. rotundatum, and also $L$. polyedra spanned from spring to autumn months, but with higher abundances. Alexandrium spp. was a typical summer genus with the highest abundance recorded in Venice $\left(4.9 \times 10^{4}\right.$ cells $\left.1^{-1}\right)-$ that largely exceeded maxima in other ports. Both Gonyaulax species had, with some exceptions, very similar temporal (spring-summer) and spatial (Bar, Pula, Trieste) distribution. In other ports, Gonyaulax spp. was present in very low numbers or even absent. Different Pseudo-nitzschia species were found in all ports. Like the majority of species, Pseudo-nitzschia spp. also had a full seasonal coverage with seasonal maxima registered in autumn and summer. However, the highest abundances differed up to four orders of magnitude $\left(10^{3}\right.$ vs. $\left.10^{7}\right)$ among ports, indicating an enormous bloom development in the ports of Pula $\left(10.3 \times 10^{6}\right.$ cells $\left.1^{-1}\right)$, Venice $\left(3.7 \times 10^{6}\right.$ cells $\left.1^{-1}\right)$, and Šibenik $\left(3.1 \times 10^{6}\right.$ cells $\left.1^{-1}\right)$.

Critical inspection of scientific literature resulted in a short list of 
Table 3

Species names and respective codes that resulted from the social network analysis and are presented in Figs. 3 and 4.

\begin{tabular}{ll}
\hline Species & Code \\
\hline Alexandrium spp. & Ale spp \\
Asterionellopsis glacialis & Ast gla \\
Cerataulina pelagica & Cer pel \\
Chaetoceros affinis & Cha aff \\
Chaetoceros curvisetus & Cha cur \\
Chaetoceros spp. & Cha spp \\
Chrysochromulina spp. & Chr spp \\
Cylindrotheca closterium & Cyl clo \\
Dictyocha fibula & Dic fib \\
Dinophysis caudata & Din cau \\
Dinophysis fortii & Din for \\
Dinophysis sacculus & Din sac \\
Ditylum brightwellii & Dit bri \\
Gonyaulax polygramma & Gon pol \\
Gonyaulax spinifera & Gon spi \\
Guinardia flaccida & Gui fla \\
Guinardia striata & Gui str \\
Hermesinum adriaticum & Her adr \\
Leptocylindrus danicus & Lep dan \\
Lingulodinium polyedra & Lin pol \\
Lioloma pacificum & Lio pac \\
Phalacroma rotundatum & Pha rot \\
Proboscia alata & Prb ala \\
Prorocentrum compressum & Pro com \\
Prorocentrum micans & Pro mic \\
Pseudo-nitzschia spp. & Pse spp \\
Skeletonema marinoi & Ske mar \\
Skeletonema spp. & Ske spp \\
Thalassionema nitzschioides & Tha nit \\
Thalassiosira gravida & Thl gra \\
Tripos furca & Tri fur \\
Tripos fusus & Tri fus \\
Tripos muelleri & Tri mue \\
\hline & \\
\hline
\end{tabular}

NIS, five in total, found in Adriatic ports (Table 5). The list is composed of three diatoms and two dinoflagellates. The entire genus Ostreopsis is benthic, as is also the freshwater diatom Didymosphenia geminata. Two taxa, Ostreopsis genus and Pseudo-nitzschia multistriata can be considered as invasive alien species since they are, besides being alien, also harmful (see Table 4). Three NIS were recorded in port of Venice, while one in ports of Ancona, Bari, Koper, Pula, Split, and Trieste. Interestingly, P. multistriata, which can be, unlike the other Pseudo-nitzschia species, easily identified under the light microscope, was found in the three northernmost Adriatic ports (Venice, Koper, and Trieste).

Twenty-three taxa were classified as cryptogenic. Because of their uncertain origin and based on the lack of sound scientific evidence, we classified them as cryptogenic instead of NIS. The highest richness was that of dinoflagellates.

\section{Discussion}

4.1. Species richness and phytoplankton community patterns of the Adriatic ports

The most important achievement of phytoplankton PBS in 12 Adriatic ports is undoubtedly the list of species and genera, which will serve as the reference point for future management of ports in view of the BWM Convention (IMO, 2004). Adriatic ports have in this way joined other ports and coastal areas worldwide (e.g. Juliano and Garcia, 2006; Marangoni et al., 2001), which recognised the importance of the implementation of the Convention in advance and prepared catalogues of various groups of organisms, phytoplankton included, through PBS.

When compared to the comprehensive floristic reviews in the Adriatic (Cabrini et al., 2010a; Cabrini et al., 2010b; Caroppo, 2010; Gómez, 2003; Viličić et al., 2002), which are compilations of numerous old and recent systematic literature, as well as of national projects and monitoring programs, our list largely agrees with these lists in terms of species richness and composition.

The sum of taxa of the two most numerous groups of our study diatoms and dinoflagellates (603) is less than the inventories made by Viličić et al. (2002) (782 taxa) and Cabrini et al. (2010a, 2010b) (752 taxa). The greatest discrepancy in species numbers is in the group of haptophytes where coccolithophorids are the predominant: 27 (our study) vs. 101 (Viličić et al., 2002) and 70 (Caroppo, 2010). According to Viličić et al. (2009), the species diversity of coccolithophorids - and even more so of other groups of nanoflagellates - cannot be compared across areas due to different methodologies of sampling and identification. In fact, in our PBS, investigators in several ports classified specimens of nanoflagellates as an unidentified group as a whole, e.g. unidentified nanophytoflagellates, or as a class, e.g. unidentified chrysophytes. Moreover, in one port only target HAOP species were taken into account, which didn't include small $(<20 \mu \mathrm{m})$ phytoflagellates.

On the basin scale, only 23 phytoplankton taxa were not reported by any of the inspected floristic literature and were therefore classified as cryptogenic species, which will be discussed later on. These numbers suggest two things: 1) despite the fact that the PBS was biased by a limited temporal coverage (six samplings in best cases), it was overcome by a thorough spatial coverage (from three to seven sampling stations in all of the studied ports) that increased the possibility of encounters, i.e. identified species; and 2) ports were found similar to neighboring coastal waters in terms of phytoplankton diversity.

Observed differences in species richness between ports can arise from numbers of samplings carried out in each port, real species richness, and/or the personnel's taxonomic skills. Our list also comprises 36 freshwater taxa, and the highest number of freshwater species was found in the port of Venice (30). More than half of freshwater taxa were diatoms (211), followed by chlorophytes (10). The specific environmental and hydrologic conditions of the Venice lagoon support a richer and salinity-tolerant algal community as a result of the varying degree of impacts, such as tides, interactions between the adjacent marine waters, and riverine inputs (Bernardi Aubry et al., 2013). Although the lowest surface salinities were measured in the ports of Šibenik and Ploče, which also accounts for the lowest average values (17.7 \pm 9.4 and $25.2 \pm 10.1$, respectively) on a limited number of measurements ( $N=12$ for both ports), relatively invariable salinities $(31.3 \pm 2.9)$ (small SD in comparison with Ploče and Šibenik) over a much greater samples size $(N=41)$ in the port of Venice reflect a relatively stable brackish environment that also supports freshwater elements.

The network analysis revealed the most characteristic taxa and seasonal community patterns in Adriatic ports. The three taxa that dominated all seasons and other seasonally-specific taxa were previously reported as characteristic for different Adriatic sub-basins (Bernardi Aubry et al., 2004; Bernardi Aubry et al., 2012; Caroppo et al., 1999a; Drakulović et al., 2012; Totti et al., 2000; Viličić et al., 2002; Viličić et al., 2009). Decades-long studies carried out in the northern Adriatic (Bernardi Aubry et al., 2004; Bernardi Aubry et al., 2012; Marić et al., 2012) revealed the same seasonal pattern as in our study for some of the aforementioned species. As the seasonally-specific examples, we report: Cyclotella spp., $P$. micans, and T. furca for spring; $P$. alata and T. fusus for summer; C. curvisetus, G. striata, and A. glacialis for autumn; and S. marinoi for winter. Moreover, Totti et al. (2000) identified Chaetoceros as spring-dominant genus of the eastern part of the middle Adriatic, which fits with our findings where Chaetoceros spp. occupied the central position in the spring community pattern. Increased dominance of Chaetoceros species in the spring and early summer bloom in the recent period (2000s) was also observed in the Gulf of Trieste (Cabrini et al., 2012; Mozetič et al., 2012). The fact that diatom Lioloma pacificum and silicoflagellate Dictyocha fibula were found to significantly increase over a 30-year long period in the western part of the northern Adriatic (Bernardi Aubry et al., 2012) supports our most recent findings of both species as important in the phytoplankton community in autumn and winter, respectively. Differences in seasonal 
Table 4

List of HAB and potentially HAB species found in net and water samples during PBS campaigns in Adriatic ports. Species in square brackets are not considered as a separate entry. Besides the presence in ports, other information is reported: harmful effects, formation of resting stages (dinoflagellate cyst and diatom resting spores. The question mark (?) denotes

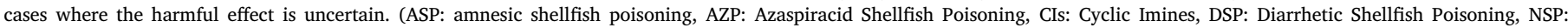
Neurotoxic Shellfish Poisoning, PSP: Paralytic Shellfish Poisoning, TTXs: tetrodotoxins, YTX/homoYTX: (homo)yessotoxin). Abbreviations of ports are reported in Table 1.

\begin{tabular}{|c|c|c|c|c|c|c|c|c|c|c|c|c|c|c|}
\hline Name & Harmful effect & Resting stage & AN & $\mathrm{BI}$ & BA & DU & KO & PL & PU & RI & ST & SI & TS & VE \\
\hline \multicolumn{15}{|l|}{ Dinophyceae } \\
\hline Akashiwo sanguinea $a^{\mathrm{a}, \mathrm{b}}$ & Fish killing & Yes & & + & & + & & + & & & + & & & \\
\hline Alexandrium minutum ${ }^{\mathrm{a}, \mathrm{b}}$ & PSP toxins & Yes & + & + & & & + & & & & + & + & & \\
\hline Alexandrium tamarense $e^{\mathrm{a}, \mathrm{b}, \mathrm{c}}$ & PSP toxins & Yes & & + & & & & + & & & + & + & & \\
\hline Alexandrium spp. ${ }^{f}$ & PSP toxins & Yes & + & + & + & + & + & + & + & + & + & + & + & + \\
\hline Amphidinium cf. operculatum ${ }^{\mathrm{b}}$ & Fish killing & Not known & & + & & & & & & & & & & \\
\hline Azadinium spp. ${ }^{d}$ & AZP toxins (?) & In some species & + & + & & & & & & & & & & \\
\hline cf. Amphidoma languida ${ }^{\mathrm{a}, \mathrm{b}}$ & AZP toxins (?) & No & + & + & & & & & & & & & & \\
\hline Coolia monotis ${ }^{\mathrm{b}, \mathrm{e}}$ & Likely to present a potential danger & Yes & & & & & & & & & + & & & \\
\hline Dinophysis acuminata ${ }^{\mathrm{a}, \mathrm{b}}$ & DSP toxins & Yes & + & + & + & & & + & + & + & & & & + \\
\hline Dinophysis acuta ${ }^{\mathrm{a}, \mathrm{b}}$ & DSP toxins & Yes & + & & + & & & & & & + & + & & + \\
\hline Dinophysis caudata ${ }^{a, b}$ & DSP toxins & Not confirmed & + & + & + & & + & + & + & + & + & + & + & + \\
\hline Dinophysis fortiia,b & DSP toxins & Not confirmed & + & + & + & & + & + & + & + & + & + & + & + \\
\hline Dinophysis infundibulum a,b & DSP toxins & Not confirmed & + & + & & & & & & & & & & \\
\hline Dinophysis ovum ${ }^{\mathrm{a}, \mathrm{b}}$ & DSP toxins & Not confirmed & + & + & & & & + & + & + & & + & & \\
\hline Dinophysis sacculus ${ }^{\mathrm{a}, \mathrm{b}}$ & DSP toxins & Not confirmed & + & + & + & & + & & + & + & + & + & + & + \\
\hline Dinophysis tripos ${ }^{\mathrm{a}, \mathrm{b}}$ & DSP toxins & Yes & + & + & + & & + & & + & + & & + & + & + \\
\hline Dinophysis spp. ${ }^{f}$ & DSP toxins & Not confirmed & + & + & & & + & & + & + & & & & \\
\hline Gonyaulax polygramma ${ }^{b}$ & High biomass & Yes & + & + & + & + & + & + & + & + & + & + & + & + \\
\hline Gonyaulax spinifera ${ }^{a, b}$ & YTX/homoYTX & Yes & + & + & + & & 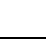 & + & + & + & + & + & + & + \\
\hline Heterocapsa triquetra ${ }^{b}$ & Amino acid BMAA & Yes (temporary) & & + & & & + & & & & & & & \\
\hline Karenia cf. bicuneiformis ${ }^{\mathrm{a}, \mathrm{b}}$ & NSP toxins & No & + & + & & & & & & & & & & \\
\hline Karenia cf. mikimotoi ${ }^{\mathrm{a}, \mathrm{b}}$ & Fish killing & No & + & + & & & & & & & & & & \\
\hline Karenia cf. selliformis ${ }^{\mathrm{a}, \mathrm{b}}$ & NSP toxins & No & + & + & & & & & & & & & & \\
\hline Karenia papilionacea ${ }^{a, b}$ & NSP toxins & No & + & + & & & & & & & & & & \\
\hline Karenia spp. ${ }^{f}$ & NSP toxins & No & + & + & & & & & & & + & + & + & \\
\hline Lingulodinium polyedra ${ }^{a, b}$ & YTX/homoYTX & Yes & + & + & + & + & + & + & + & & + & & + & + \\
\hline Ostreopsis cf. ovata ${ }^{a, b, e}$ & PLTXs & Yes & & & & & & & + & & + & & & \\
\hline Ostreopsis spp.g.e & PLTXs & Yes & & + & & & & & & & & & & \\
\hline Phalacroma mitra ${ }^{\mathrm{a}, \mathrm{b}}$ & DSP toxins & No/unknown & + & + & & & + & & & + & + & & + & \\
\hline Phalacroma rotundatum ${ }^{\mathrm{a}, \mathrm{b}}$ & DSP toxins & No/unknown & + & + & + & & + & + & + & + & + & + & + & + \\
\hline Prorocentrum cf. emarginatum a,b,e & Likely to present a potential danger & Yes & & & & & & & & & & & & + \\
\hline Prorocentrum cordatum ${ }^{\mathrm{a}, \mathrm{b}}$ & High biomass/TTXs (?)i & Yes & + & + & + & + & + & & + & + & + & + & + & + \\
\hline Prorocentrum lima $a^{\mathrm{a}, \mathrm{b}, \mathrm{e}}$ & DSP toxins+Clsj & Yes & & + & + & & + & & & & + & & & + \\
\hline Prorocentrum rhathymum a,b,e & DSP toxins + Clsj & No/unknown & & + & & & & & & & & & & + \\
\hline Protoceratium reticulatuma,b & YTX/homoYTX & Yes & + & + & & & + & & & & & & + & + \\
\hline
\end{tabular}

0.5

Bacillariophyta

\begin{tabular}{|c|}
\hline Chaetoceros convolutus $^{\mathrm{b}}$ \\
\hline Chaetoceros debilis $^{\mathrm{b}}$ \\
\hline Chaetoceros peruvianus $^{\mathrm{b}}$ \\
\hline Chaetoceros wighamii ${ }^{\mathrm{a}}$ \\
\hline Halamphora cf. coffeiformis ${ }^{\mathrm{a}, \mathrm{b}, \mathrm{e}}$ \\
\hline Pseudo-nitzschia cf. callianth $a^{\mathrm{a}, \mathrm{b}}$ \\
\hline Pseudo-nitzschia delicatissima ${ }^{a, b}$ \\
\hline Pseudo-nitzschia fraudulenta ${ }^{\mathrm{a}, \mathrm{b}}$ \\
\hline [Pseudo-nitzschia cf. fraudulenta] \\
\hline Pseudo-nitzschia galaxiae ${ }^{\mathrm{a}, \mathrm{b}}$ \\
\hline [Pseudo-nitzschia cf. galaxiae] \\
\hline Pseudo-nitzschia multistrata ${ }^{\mathrm{a}, \mathrm{b}}$ \\
\hline Pseudo-nitzschia pungens ${ }^{\mathrm{a}, \mathrm{b}}$ \\
\hline Pseudo-nitzschia seriata ${ }^{\mathrm{a}, \mathrm{b}}$ \\
\hline Pseudo-nitzschia spp. ${ }^{f}$ \\
\hline
\end{tabular}

\begin{tabular}{|l|l|}
\hline Fish killing & Unknown \\
\hline Fish killing & Yes \\
\hline Fish killing & Unknown \\
\hline Fish killing & Yes \\
\hline ASP toxin & Unknown \\
\hline ASP toxin & No \\
\hline ASP toxin & No \\
\hline ASP toxin & No \\
\hline ASP toxin & No \\
\hline ASP toxin & No \\
\hline ASP toxin & No \\
\hline ASP toxin & No \\
\hline ASP toxin & No \\
\hline ASP toxin & No \\
\hline ASP toxin & No \\
\hline
\end{tabular}

\begin{tabular}{|c|c|c|c|c|c|c|c|c|c|c|c|}
\hline & & + & + & & + & + & & + & & & \\
\hline & & & & & & + & + & & & & \\
\hline & + & & & & & + & + & + & + & + & \\
\hline & & & & + & + & + & + & + & & & \\
\hline & & & & & & & & & & & + \\
\hline & & & & + & & & & & & & \\
\hline & & & & & & + & + & & & & + \\
\hline & & & & & & + & & & & & \\
\hline & & & & & & & & & & & + \\
\hline & & & & & & & & & & & + \\
\hline & & & & & & & & & & + & \\
\hline & & & & + & & & & & & + & + \\
\hline+ & + & & & & & & & & & & + \\
\hline & & & & & & + & + & & & & \\
\hline+ & + & + & + & + & + & + & + & + & + & + & + \\
\hline
\end{tabular}


Table 4 (continued)

\begin{tabular}{|c|c|c|c|c|c|c|c|c|c|c|c|c|c|c|}
\hline Name & Harmful effect & Resting stage & AN & $\mathrm{BI}$ & $\mathrm{BA}$ & DU & KO & $\mathrm{PL}$ & PU & $\mathrm{RI}$ & ST & SI & TS & VE \\
\hline \multicolumn{15}{|l|}{0.5} \\
\hline \multicolumn{15}{|l|}{ Haptophyta } \\
\hline Chrysochromulina spp. ${ }^{\text {h }}$ & Fish killing (?) & Probably & + & + & & & & + & & & + & + & & \\
\hline \multicolumn{15}{|l|}{0.5} \\
\hline \multicolumn{15}{|l|}{ Ochrophyta } \\
\hline Dictyocha speculumb & Fish killing & Probably & & + & + & & + & + & + & + & & + & + & + \\
\hline Vicicitus globosus ${ }^{\mathrm{a}, \mathrm{b}}$ & Fish killing & Unknown & + & + & & & & & & & & & & \\
\hline Heterosigma akashiwo & Fish killing/NSP toxinsk & Yes & & & & & & & & & & & & + \\
\hline
\end{tabular}

${ }^{a}$ Included in the UNESCO IOC Taxonomic Reference List of Harmful Micro Algae (Moestrup et al., 2009 onwards).

b Reported by Lassus et al. (2016).

$\S$ See John et al. (2014) for explanation.

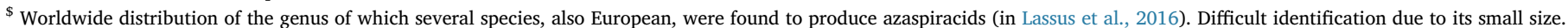

$¥$ Benthic species found in net and water samples.

\# Exception: unable to identify species, but many are toxic.

++ Exception: five out of nine species are recognized as toxic, among them also O. ovata, which is present in the Adriatic.

+++ Exception: unable to identify species, several species form toxic blooms.

* See Vlamis et al. (2015).

** See Davidson et al. (2015).

**** In Seafood and Freshwater Toxins: Pharmacology, Physiology, and Detection (Botana, L.M. (Ed.), 2014).

species

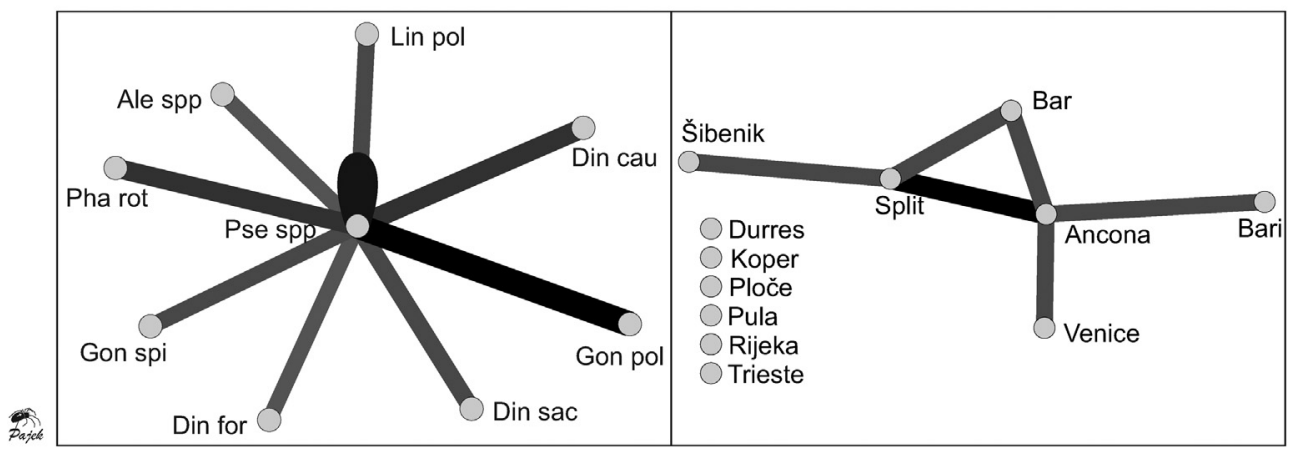

Fig. 4. Network analysis of HAB species. Left panel: subnetwork of the most important harmful taxa (by spatial occurrence in ports and relative abundance) found in net samples during PBS campaigns in Adriatic ports. Right panel: connections between similar ports based on the number of same species found in those ports and their relative abundance. Ports that are more similar are depicted closer. The weight of connecting lines between two species/ports is denoted by the thickness and depicted with a gray scale. Species codes and respective names are listed in Table 3. patterns between our study and other mentioned studies from the northern Adriatic were in the predominant non-diatom species. Some differences can be ascribed to different methodological approaches: while in our analysis we considered net samples, Viličić et al. (2009) analysed water samples revealing small dinoflagellates $(<20 \mu \mathrm{m})$ as the prevailing ones. Two species that shaped seasonal patterns in Adriatic ports but were not found as dominant in the Adriatic by the previous studies (ibid.) were Hermesinum adriaticum in summer and Chrysochromulina spp. in winter. Despite that, we obtained comparable results with previous phytoplankton studies in the Adriatic. This indicates a stable and recurrent species succession of dominating taxa in the Adriatic coastal communities, "specific" environments as ports included.

Our results are somehow influenced by the all seasons-round dominance of Chaetoceros spp. and Pseudo-nitzschia spp. The two genera, but especially Pseudo-nitzschia are difficult to discern at the species level using only a light microscope. Behind both genera can be hidden several species with a clear temporal succession, as evidenced by Bosak et al. (2016) for Chaetoceros and Caroppo et al. (2005), Ljubešić et al. (2011), Grbin et al. (2017), Marić et al. (2011), and Pistocchi et al. (2012) for Pseudo-nitzschia by applying careful morphologic and/or molecular methods. We nevertheless identified 45 Chaetoceros and seven Pseudo-nitzschia species unevenly distributed among the 12 Adriatic ports, but the poor taxonomic resolution resulted in the prevalence of the whole genera in terms of seasonal and spatial coverage.
In particular, identification of Pseudo-nitzschia species should be carefully considered since the number of described species more than doubled over the last 30 years in the world's oceans, which includes also toxigenic species (Trainer et al., 2012). This recalls, as in the case of unidentified nanophytoplankton, and wherever routine light microscopy does not allow correct identification, use of advanced molecular methods for detecting phylogenetic relationships.

The second part of the network analysis provided information about similarities between Adriatic ports (Fig. 3, right panel). In general, the greatest similarities were found between ports, which were analysed by the same laboratories (see Table 2; e.g. Ancona and Bari, Pula and Rijeka). The next most evident outcome is the tight connection between middle Adriatic ports on the western (Ancona) and eastern side (Split) of the basin and between ports along the western coast (Ancona and Venice). The same is also true when only HAB communities are considered (Fig. 4, right panel). We compared the similarities between certain ports to the overall cyclonic character of the general surface circulation of the Adriatic Sea, constituted by three cyclonic gyres located in the southern, central, and northern sub-basins, and by the two coastal currents with seasonally varying characteristics (Artegiani et al., 1997b). The two coastal currents transporting water masses southward along the western coast and northward along the eastern coast could support similar phytoplankton community between Venice, Ancona, and Bari, and between ports on the eastern coast, respectively. Eastern Adriatic ports, with the exception of Venice on the western side, formed 
a net of connections among Bar, Šibenik, Rijeka, and Pula during winter, which coincides with the eastern Adriatic coastal current being narrower in that season and flowing close to the coast (Zavatarelli and Pinardi, 2003). Furthermore, intense bora wind episodes in the Kvarner Bay in autumn induce the circulation towards the western coast, thus providing an explanation for the similarity between the northeastern ports, Pula and Rijeka, and western one, Ancona and Bari. Since recent investigation of the same project, i.e. the BALMAS project, indicates the middle Adriatic cyclonic gyre to be directed southwesterly from the central eastern region (close to Split) towards the central western region (considerably southern from Ancona) in winter, spring, and summer, the similarity between Split and Ancona fails to be facilitated by a circulation pattern (unpublished results). The gyre is directed westward towards Ancona only in the autumn, and is also the strongest when compared to other seasons. Thus, this indicates the feasibility of a naturally induced similarity between the two ports. In other seasons, results sustain the hypothesis of marine traffic inducing similarity of phytoplankton communities. The strongest similarity, noted in spring and summer, may be related to the more intense passenger traffic between the ports of Split and Ancona during warmer part of the year operated by the largest Croatian (http://www.jadrolinija.hr/en/sailingschedule/international-lines-2017) and Italian (https://www.snav.it/ en/orari-e-tratte) shipping companies. In contrast, the strong connection between southern ports, Bar and Bari, in autumn could be due to the well-defined southern Adriatic gyre.

In general, two main factors may have induced the similarity between ports: the natural circulation pattern and the anthropogenic transport of water masses via ballast tanks on ships. There is in fact an intense maritime traffic among the ports of the Adriatic (Penko et al., 2016), but it is difficult to say to what extent it shapes phytoplankton communities and subsequently similarities between ports. One thing is the introduction of non-native species via ballast waters, but as planktonic organisms they then easily "colonise" the new environments through natural dispersal in the same way as autochthonous communities do.

\subsection{Harmful native and non-indigenous phytoplankton in Adriatic ports}

From one of the earliest recognitions of their global increase (Hallegraeff, 1993), HAB have been extensively studied worldwide and were recognised as an important phenomenon that addresses not only the research community, but also the wider society. The very recent compilation of HAB species in the world oceans, which addresses various aspects of $\mathrm{HAB}$, from taxonomy, biogeography, ecology, toxinology, and toxicology to management and societal needs (Lassus et al., 2016), together with the IOC-UNESCO taxonomic list (Moestrup et al., 2009 onwards) helped us to select HAB species sampled during PBS.

Our list of HAB comprises 52 taxa. The majority of these taxa (34) have the potential to produce toxins, which are involved in seafood poisoning in humans or can have deleterious effects on marine wildlife (the first out of five categories of HAB sensu Hallegraeff et al., 2004). Despite their potential to produce chemically diverse toxins (see Table 4), the only ones that are frequently found above the regulatory limits in the Adriatic shellfish are from the okadaic acid and yessotoxin groups (Fattorusso et al., 1992; Francé and Mozetič, 2006; Ninčević Gladan et al., 2008; Sedmak and Fanuko, 1991). While the okadaic acid group associated with genera Dinophysis and Phalacroma and benthic Prorocentrum lima and P. rathymum provokes DSP syndromes, yessotoxins produced by Protoceratium reticulatum, Lingulodinium polyedra, and Gonyaulax spinifera have no proven effect on humans (EFSA, 2008). Nevertheless, yessotoxins were found to be the predominant toxins in mussels from the eastern Adriatic coast during 2000s (Ninčević Gladan et al., 2010b). A responsible control on toxins in seafood carried out through national monitoring programs in Adriatic countries is the probable reason for very rare cases of human intoxication with DSP toxins (in Pistocchi et al., 2012). Pseudo-nitzschia species and Halamphora coffeiformis are potential producers of domoic acid, which can induce ASP syndromes; domoic acid is occasionally detected in mussels from the Adriatic Sea (Arapov et al., 2016; Ciminiello et al., 2005; Ujević et al., 2010), but always below the regulatory limit. Also PSP toxins, produced by Alexandrium species are sporadically detected (Ujević et al., 2012) with only one registered case of PSP intoxication so far (Honsell et al., 1996).

Among other toxins that were recently found in Adriatic mussels (Bacchiocchi et al., 2015) or toxins that can potentially emerge because of the presence of causative organisms, there are azaspiracids and brevetoxins, respectively. Azaspiracids are produced by the dinoflagellate genus Azadinium, which was for a long time neglected in the phytoplankton community due to its small, nanoplanktonic size (Salas et al., 2011). Brevetoxins are produced by several species of the dinoflagellate Karenia, a world wide spread genus, which are also present in the Mediterranean Sea (Feki-Sahnoun et al., 2017; Zingone et al., 2006) but only recently recorded in the Adriatic in a sporadic way (Cangini, Francé, unpublished results).

Despite a practically uniform toxin profile in contaminated Adriatic shellfish, i.e. DSP and yessotoxins, an extensive study performed on cultured microalgae from the NW Adriatic has nevertheless showed that nine species were able to synthesize toxins belonging to a wider range of chemical groups (Pistocchi et al., 2012). Seven out of nine species analysed by Pistocchi et al. (2012) were found in our study. This poses a potential threat for already mentioned syndromes (DSP, ASP, and PSP), but also for respiratory distress caused by palytoxins in Ostreopsis species and fish kills caused by raphidophytes. Fortunately, the absence of reported fish kills is probably due to low ichthyotoxicity of Adriatic raphidophytes (Pistocchi et al., 2012), of which Heterosigma akashiwo and formerly classified Chattonella globosa (now silicoflagellate Vicicitus globosus) were found in ports of Venice and of Ancona and Bari, respectively. The genus Ostreopsis was initially described from tropical waters, but in recent decades Ostreopsis blooms have also become common in temperate areas and regularly occur in the Mediterranean Sea during summer-early autumn (Aligizaki and Nikolaidis, 2006; Mangialajo et al., 2011) as morphotypes $O$. cf. ovata and $O$. cf. siamensis (Penna et al., 2012). The Adriatic Sea is not excluded from this increasing phenomenon. After its first recorded appearance in 2001 in the southern Adriatic, which was also correlated with human and animal suffering (Gallitelli, 2005), blooms of $O$. cf. ovata were intermittently observed on the rocky shores along the western (Ingarao et al., 2009; Totti et al., 2010), as well as the eastern (Cabrini et al., 2010c; Ninčević Gladan et al., 2016) Adriatic coast.

In the groups of non-toxic high biomass fish killing species, and of species that are likely to present a potential danger sensu Hallegraeff et al. (2004), we classified diatoms from the genus Chaetoceros, few dinoflagellates (e.g. largely distributed and abundant Prorocentrum cordatum) and haptophytes. As in the case of raphidophytes, no cases of fish kills due to physical damage have ever been observed in the Adriatic when these taxa bloomed, the Chaetoceros species in particular.

The number of $\mathrm{HAB}$ species in specific ports followed the same pattern, as in the case of total phytoplankton community: the ports of Bari, Ancona, and Venice had the highest species richness, while that of Durres was the lowest. It is not surprising that among 52 HAB taxa the network analysis selected the nine most important species (Fig. 4) which are or could be potentially responsible for the most common shellfish intoxications in the Adriatic, and are regular members of phytoplankton community (Francé and Mozetič, 2006; Ljubešić et al., 2011; Marasović et al., 2007) in contrast to emerging or sporadically present taxa (e.g. Karenia, Azadinium, Ostreopsis). Apart from Pseudonitzschia and Alexandrium genus, all other taxa were easily identified to the species level. As long as an advanced methodology will not enable a rapid species identification during routine monitoring, the whole genera should be considered as harmful.

As in the case of seasonally specific phytoplankton communities, the 

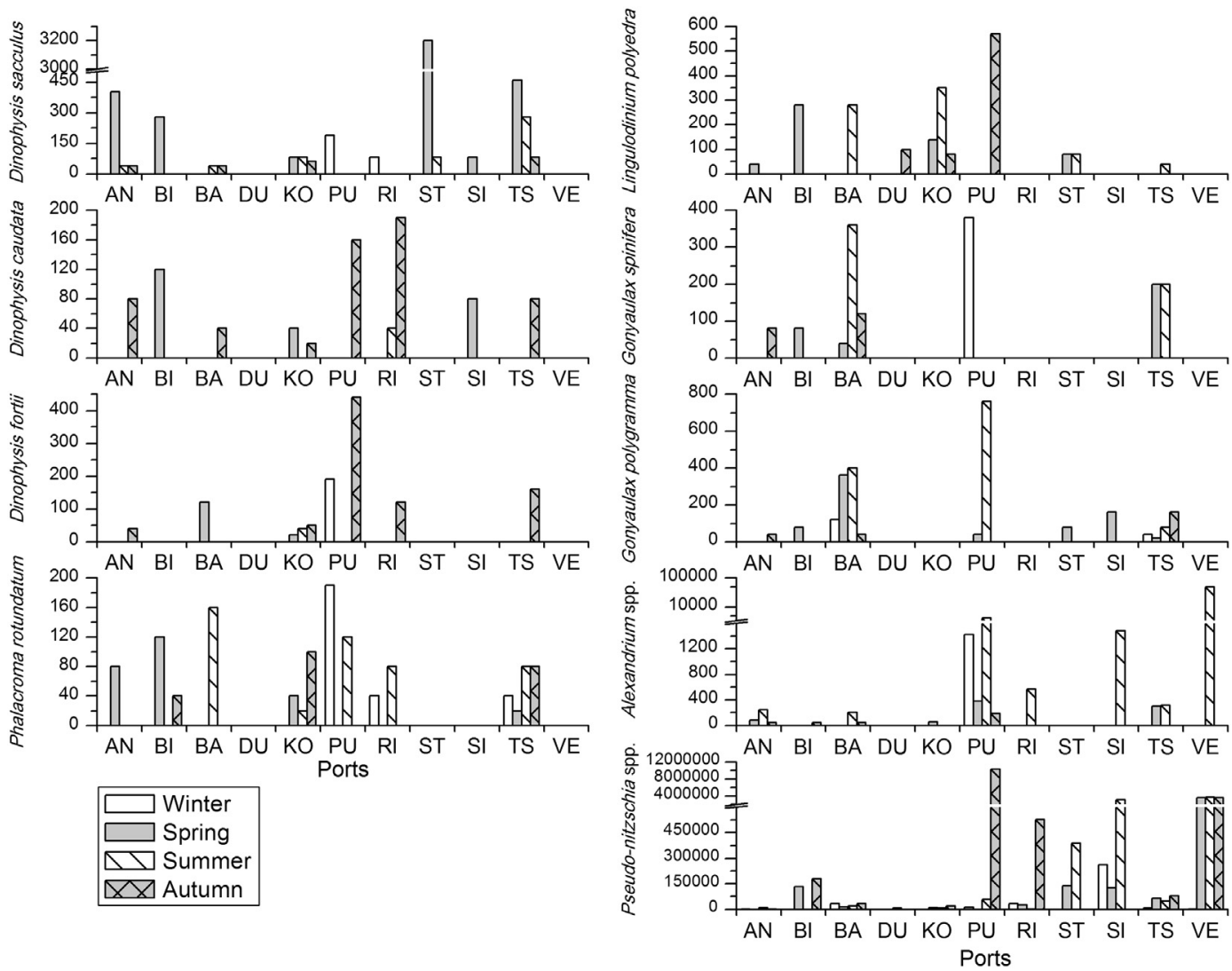

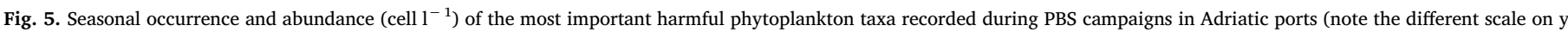
axis). (AN: Ancona, BI: Bari, BA: Bar, DU: Durres, KO: Koper, PU: Pula, RI: Rijeka, ST: Split, SI: Šibenik, TS: Trieste, VE: Venice).

same ports expressed a high level of similarity. Since most species on the left side of Fig. 4 are preferentially warmer-water species, this could be in line with the predominant surface circulation in the Adriatic during warmer period, which is in turn reflected in the connection between ports of Split and Ancona (Fig. 4, right panel). The central position of Pseudo-nitzschia spp. is also corroborated by the more detailed distribution and its absolute abundances (see Fig. 5). Although present in all seasons, Pseudo-nitzschia spp. attained bloom levels during autumn and summer months in certain ports (Pula, Rijeka, Split, Šibenik, Venice). Some strains of Pseudo-nitzschia species, i.e. P. multistriata and $P$. galaxiae, from the Mediterranean and Adriatic Sea were already recognised as being capable of producing toxins (Pistocchi et al., 2012; Zingone et al., 2006). The same two species, which have recognisable morphologic characteristics under the light microscope, were also detected with a high level of confidence in our study. All these facts address the need for setting up monitoring of HAOP in ports. Special attention should be paid during the development of the bloom of Pseudo-nitzschia, since is known that the production of domoic acid in many Pseudo-nitzschia species increases in the stationary phase of growth (e.g. Fehling et al., 2005; Trainer et al., 2009).

Dinophysis species and Phalacroma rotundatum followed the wellestablished seasonal succession pattern and abundances characteristic for the northern (Bernardi Aubry et al., 2000; Francé and Mozetič, 2006) and southern Adriatic (Caroppo et al., 1999b; Caroppo et al., 2001), and for the eastern coast of the central Adriatic (Ninčević Gladan et al., 2008).

Alexandrium species were, in general, the most abundant in summer and except for one sampling in port of Venice always recorded in low abundances (below $5 \times 10^{3}$ cells $1^{-1}$ ). Two identified Alexandrium species in Adriatic ports, $A$. minutum and $A$. tamarense (sometimes also referred as $A$. tamarense species complex) and possibly other cryptic species forming the pool of Alexandrium spp. are potentially toxic (for the Adriatic A. minutum strain confirmed toxicity in culture; in Pistocchi et al., 2012). However, they very rarely reach bloom magnitudes of several millions cells per liter in coastal waters of the Adriatic (Boni et al., 1986; Milandri et al., 2005), and likewise in other parts of the Mediterranean suffering PSP intoxication (Lugliè et al., 2003; Vila et al., 2001). Despite several pending issues (taxonomy, toxinology) regarding this genus and relatively low abundance, potential monitoring plans should take into account the cysts that Alexandrium are known to produce and which are buried in sediment.

The majority of HAB species found in the Adriatic ports are thought to be native, and only few were classified as non-indigenous with great confidence. There is vast literature of non-indigenous phytoplankton in European seas (Gómez, 2008 and references therein; databases such as AquaNIS, DAISIE and EASIN). Gómez (2008) argued that behind this literature there is usually not a critical study of the validity of NIS due to a decrease in taxonomic expertise (Cotterill, 1995), underinvestigation, undersampling, or a marginal dispersal of species. All these factors are probably at the origin of the extremely low number of proven invaders among phytoplankton species in the Mediterranean Sea (Zingone, 2015).

In our study five taxa were classified as NIS and seven ports acted as "hubs," namely Ancona, Bari, Koper, Pula, Split, Trieste, and Venice (Table 5). Among NIS there are three harmful marine (Pseudo-nitzschia multistriata, Ostreopsis cf. ovata and Ostreopsis sp.) and one freshwater taxa (Didymosphenia geminata). For the fifth NIS, diatom Skeletonema tropicum, harmful effects are not known. P. multistriata was described from Japanese seas and were first observed in western Italian coastal waters in 1995 (Zingone et al., 2003). Also, later they were found in Greece (Moschandreou and Nikolaidis, 2010) and the western Adriatic (Pistocchi et al., 2012). In our study, they were found in the three northernmost Adriatic ports, Venice, Trieste, and Koper, sharing busy marine traffic (Penko et al., 2016). The fact that P. multistriata was 
Table 5

List of NIS and cryptogenic species found in net and water samples during PBS campaigns in Adriatic ports. Abbreviations of ports are reported in Table 1.

\begin{tabular}{|c|c|c|c|c|c|c|c|c|c|c|c|c|}
\hline NIS & AN & $\mathrm{BI}$ & $\mathrm{BA}$ & DU & KO & $\mathrm{PL}$ & $\mathrm{PU}$ & RI & ST & SI & TS & VE \\
\hline \multicolumn{13}{|l|}{ Bacillariophyta } \\
\hline Didymospheniageminata ${ }^{\mathrm{a}}$ & & & & & & & & & & & & + \\
\hline Pseudo-nitzschia multistriata & & & & & + & & & & & & + & + \\
\hline Skeletonema tropicum & + & & & & & & & & & & & + \\
\hline \multicolumn{13}{|l|}{0.5} \\
\hline \multicolumn{13}{|l|}{ Dinophyceae } \\
\hline Ostropsis cf. ovata & & & & & & & + & & + & & & \\
\hline Ostreopsis sp. & & + & & & & & & & & & & \\
\hline \multicolumn{13}{|l|}{1.0} \\
\hline \multicolumn{13}{|l|}{ Bacillariophyta } \\
\hline Amphora alata & & + & & & & & & & & & & \\
\hline Amphora cf. proboscidea & & + & & & & & & & & & & \\
\hline cf. Campylodiscus noricus & + & + & & & & & & & & & & \\
\hline Chaetoceros cf. pseudodichaetus & & & & & + & & & & & & & \\
\hline Plagiodiscus enervatus & & & & & & + & & & & & & \\
\hline Skeletonema grevillei & & & & & & & + & + & & & & \\
\hline Thalassiosira aestivalis & & & & & & + & & & & & & \\
\hline \multicolumn{13}{|l|}{0.5} \\
\hline \multicolumn{13}{|l|}{ Dinophyceae } \\
\hline cf. Amphidoma languida & + & + & & & & & & & & & & \\
\hline cf. Azadinium caudatum var. margalefii & + & & & & & & & & & & & \\
\hline cf. Dinophysis laevis & & + & & & & & & & & & & \\
\hline Dinophysis cf. bibulbus & + & + & & & & & & & & & & \\
\hline Dinophysis cf. equalanti & + & + & & & & & & & & & & \\
\hline Dinophysis elongata & & & & & & & + & & & & & \\
\hline Dinophysis rudgei & - & & & & & & & & + & & & \\
\hline Protoceratium cf. globosum & + & & & & & & & & & & & \\
\hline Protoperidinium fatulipes & 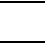 & & & & & & + & & & & & \\
\hline Tripos cf. divaricatus & & & & & & & & & & & + & + \\
\hline \multicolumn{13}{|l|}{0.5} \\
\hline \multicolumn{13}{|l|}{ Chlorophyta } \\
\hline Pterosperma cristatum & + & + & & & & & & & & & & \\
\hline \multicolumn{13}{|l|}{0.5} \\
\hline \multicolumn{13}{|l|}{ Ochrophyta } \\
\hline Vicicitus globosus $^{\mathrm{b}}$ & + & + & & & & & & & & & & \\
\hline \multicolumn{13}{|l|}{0.5} \\
\hline \multicolumn{13}{|l|}{ Cyanobacteria } \\
\hline Chamaesiphon spp. & + & & & & & & & & & & & \\
\hline Merismopedia spp. & & + & & & & & & & & & & \\
\hline \multicolumn{13}{|l|}{0.5} \\
\hline \multicolumn{13}{|l|}{ Katablepharidophyta } \\
\hline Leucocryptos marina & & & & & & & & & & & + & \\
\hline \multicolumn{13}{|l|}{0.5} \\
\hline \multicolumn{13}{|l|}{ Cercozoa } \\
\hline Paulinella ovalis & & & & & & & & & & & + & + \\
\hline
\end{tabular}

${ }^{\text {\# }}$ Freshwater species.

* In the last decade this species is been registered (as Chattonella marina) in the middle-north Adriatic Sea during the activity of monitoring.

almost simultaneously recorded in ballast tanks of ships arriving in the port of Koper (Cabrini et al., in press) and in seawater samples of the same port could be of sole coincidence or an introduction event. From 2015 onwards, this species has been regularly observed in the phytoplankton community of the southeastern part of the Gulf of Trieste (Francé, unpublished results), while in the northern part of the Gulf it was already recorded in 2005 (Cerino, unpublished results).

The same approach of distinctive morphology, as well as of distinct ecological niche, was useful in the identification of Skeletonema tropicum, which was observed for the first time along western Italian coasts in 2002 (Zingone, 2015). Ostreopsis cf. ovata was considered a NIS already by Streftaris et al. (2005), but Gómez (2008) contradicted the Streftaris list arguing the species has been simply underinvestigated to draw a firm conclusion on its origin. Some years later Zingone (2015) and Corriero et al. (2016) classified Ostreopsis cf. ovata as NIS based on molecular data, which proved this species of wide genetic diversity 
(Penna et al., 2010) as NIS for Mediterranean.

The invasive benthic diatom Didymosphenia geminata, whose occurrence is so far restricted to the Venice lagoon, is a particular case since her natural environments are cold and oligotrophic freshwater bodies (Krammer and Lange-Bertalot, 1995). Interestingly, it can also evidently survive and proliferate in brackish and eutrophic marine environment, as is the case of port of Venice. Other records of this species from marine and estuarine ecosystems are from the English Channel (Guilloux et al., 2013; Jouenne et al., 2007). There are two aspects of the increased scientific notoriety of this species: its invasiveness, i.e. from the Northern to the Southern hemispheres in the last decade and its massive proliferation in rivers and lakes having different negative consequences on a global scale (Bray et al., 2017; Spaulding and Elwell, 2007). Besides negatively affecting the recreational, aesthetic, and economic values of rivers, D. geminata blooms can adversely affect river ecosystems (Kilroy and Unwin, 2011). This would suggest observing its range of expansions and ecological valence regarding salinity and nutrient concentrations in transitional and coastal waters.

The list of cryptogenic species whose origin is uncertain was pragmatically prepared taking into account the absence of their records from the vast Mediterranean literature. We are, however, aware that this list is not a completed work and it demands further studies to determine the geographic origin of species, which goes beyond the scope of this paper.

\subsection{Conclusions}

This is the first comprehensive study of phytoplankton diversity in Adriatic ports, which revealed species richness and community structure similar to the Adriatic coastal waters.

Among 52 HAB taxa that are the core of phytoplankton HAOP the most recurrent species are those that currently provoke, or have the potential to provoke most of the harmful events (Alexandrium spp., Dinophysis spp., Pseudo-nitzschia spp.), and/or have an important role in the phytoplankton communities. While the majority of HAB species are native, a few non-indigenous species have already established stable populations in certain coastal areas (Pseudo-nitzschia multistriata, Ostreopsis cf. ovata). Taking into account their seasonal distribution, abundance, biological traits (i.e. resting stages), and relevance for ballast water uptake following Regulation C-2 of the BWM Convention, monitoring of the Early Warning System should consider seasonallyoriented surveillance of Pseudo-nitzschia and Ostreopsis species. For other HAB species, local (i.e. in certain ports) ad hoc alerts during unusual events should apply.

National monitoring programs following European directives (MSFD/2008/58/EC, WFD/2000/60/EC) can represent an important source of information since they cover wide spatial and temporal scales, and thus can act as alerts for port authorities for focused monitoring. An effort must be undertaken to gather stakeholders from different sectors (environment, maritime traffic, food and human health security) towards economically rational surveillance that will produce rapid, reliable and cost-effective results. In this perspective, advanced techniques based on molecular methods will in the future play an important role.

Supplementary data to this article can be found online at https:// doi.org/10.1016/j.marpolbul.2017.12.029.

\section{Acknowledgements}

This publication has been produced with the financial assistance of the IPA Adriatic Cross-Border Cooperation Programme - strategic project Ballast Water Management System for Adriatic Sea Protection (BALMAS) (Project Code $1{ }^{\circ}$ str./0005). The contents of this publication are the sole responsibility of authors and can under no circumstances be regarded as reflecting the position of the IPA Adriatic Cross-Border Cooperation Programme Authorities. The authors are grateful to Mr. Milijan Šiško for drawings and to Mr. Robert McKenzie and Ms. Dzifa
Denutsui for English proofreading of the text.

\section{References}

Aligizaki, K., Nikolaidis, G., 2006. The presence of the potentially toxic genera Ostreopsis and Coolia (Dinophyceae) in the North Aegean Sea, Greece. Harmful Algae 5, 717-730. http://dx.doi.org/10.1016/j.hal.2006.02.005.

Arapov, J., Ujević, I., Ninčević Gladan, Ž., Skejić, S., Ceredi, A., Milandri, A., Pigozzi, S., Riccardi, E., Vilar-González, A., Rodríguez-Velasco, M.L., Nazlić, N., Marasović, I., 2015. Shellfish lipophilic toxin profile and toxic phytoplankton species along eastern Adriatic coast. Fresenius Environ. Bull. 24, 4799-4806.

Arapov, J., Ujević, I., Marić Pfannkuchen, D., Godrijan, J., Bakrač, A., Ninčević Gladan, Ž., Marasović, I., 2016. Domoic acid in phytoplankton net samples and shellfish from the Krka River estuary in the Central Adriatic Sea. Mediterr. Mar. Sci. 17, 340-350. http://dx.doi.org/10.12681/mms.1471.

Artegiani, A., Paschini, E., Russo, A., Bregant, D., Raicich, F., Pinardi, N., 1997a. The Adriatic Sea general circulation. Part I: air-sea interactions and water mass structure. J. Phys. Oceanogr. 27, 1492-1514 (10.1175/1520-0485(1997) $027<$ 1492:TASGCP > 2.0.CO;2).

Artegiani, A., Paschini, E., Russo, A., Bregant, D., Raicich, F., Pinardi, N., 1997b. The Adriatic Sea general circulation. Part II: baroclinic circulation structure. J. Phys. Oceanogr. 27, 1515-1532.

Awad, A., Haag, F., Anil, A.C., Abdulla, A., 2014. GEF-UNDP-IMO GloBallast Partnerships Programme, IOI, CSIR-NIO and IUCN. In: Guidance on Port Biological Baseline Surveys. GloBallast Monograph No. 22 GEF-UNDP-IMO GloBallast Partnerships, London, UK.

Bacchiocchi, S., Siracusa, M., Ruzzi, A., Gorbi, S., Ercolessi, M., Cosentino, M.A., Ammazzalorso, P., Orletti, R., 2015. Two-year study of lipophilic marine toxin profile in mussels of the North-central Adriatic Sea: first report of azaspiracids in Mediterranean seafood. Toxicon 108, 115-125. http://dx.doi.org/10.1016/j.toxicon. 2015.10.002.

Batagelj, V., Mrvar, A., 2004. Pajek - analysis and visualization of large networks. In: Jünger, M., Mutzel, P. (Eds.), Graph Drawing Software. Springer (Series Mathematics and Visualization), Berlin, Heidelberg, pp. 77-103.

Bernardi Aubry, F., Berton, A., Bastianini, M., Bertaggia, R., Baroni, A., Socal, G., 2000 Seasonal dynamics of Dinophysis in coastal waters of the NW Adriatic Sea. Bot. Mar. 43, 423-430. http://dx.doi.org/10.1515/BOT.2000.044.

Bernardi Aubry, F., Berton, A., Bastianini, M., Socal, G., Acri, F., 2004. Phytoplankton succession in a coastal area of the NW Adriatic, over a 10 year sampling period (1990-1999). Cont. Shelf Res. 24, 97-115. http://dx.doi.org/10.1016/j.csr.2003.09. 007.

Bernardi Aubry, F., Cossarini, G., Acri, F., Bastianini, M., Bianchi, F., Camatti, E., De Lazzari, A., Pugnetti, A., Solidoro, C., Socal, G., 2012. Plankton communities in the northern Adriatic Sea: patterns and changes over the last 30 years. Estuar. Coast. Shelf Sci. 115, 125-137. http://dx.doi.org/10.1016/j.ecss.2012.03.011.

Bernardi Aubry, F., Acri, F., Bianchi, F., Pugnetti, A., 2013. Looking for patterns in the phytoplankton community of the Mediterranean microtidal Venice Lagoon: evidence from ten years of observations. Sci. Mar. 77, 47-60. https://doi.org/10.3989/scimar. 03638.21A.

Blanco, S., Ector, L., 2009. Distribution, ecology and nuisance effects of the freshwater invasive diatom Didymosphenia geminata (Lyngbye) M. Schmidt: a literature review. Nova Hedwigia 88, 347-422. http://dx.doi.org/10.1127/0029-5035/2009/00880347.

Boni, L., Pompei, M., Reti, M., 1986. Maree colorate e fioriture algali lungo la costa dell'Emilia-Romagna dal 1082 al 1985 con particolare riguardo alla comparsa di Protogonyaulax tamarensis. Nova Thalass. 8 (Suppl. 3), 237-245.

Bosak, S., Godrijan, J., Šilović, T., 2016. Dynamics of the marine planktonic diatom family Chaetocerotaceae in a Mediterranean coastal zone. Estuar. Coast. Shelf Sci. 180, 69-81. https://doi.org/10.1016/j.ecss.2016.06.026.

Botana, L.M. (Ed.), 2014. Seafood and Freshwater Toxins: Pharmacology, Physiology, and Detection, Third Edition. CRC Press, Taylor and Francis Group, Boca Raton, FL (1215 p.).

Bray, J., O'Brien, J., Harding, J.S., 2017. Production of phosphatase and extracellular stalks as adaptations to phosphorus limitation in Didymosphenia geminata (Bacillariophyceae). Hydrobiologia 784, 51-63. http://dx.doi.org/10.1007/s10750016-2851-2.

Bužančić, M., Ninčević Gladan, Ž., Marasović, I., Kušpilić, G., Grbec, B., 2016. Eutrophication influence on phytoplankton community composition in three bays on the eastern Adriatic coast. Oceanologia 58, 302-316. http://dx.doi.org/10.1016/j. oceano.2016.05.003.

Cabrini, M., Bastianini, M., Guardiani, B., 2010a. Le dinoficee/Dinoflagellates. Biol. Mar. Mediterr. 17 (Suppl. 1), 688-690.

Cabrini, M., Bernardi Aubry, F., Guardiani, B., 2010b. Le diatomee/diatoms. Biol. Mar. Mediterr. (Suppl. 1), 686-688.

Cabrini, M., Fornasaro, D., Lipizer, M., Guardiani, B., 2010c. First report of Ostreopsis cf. ovata bloom in the Gulf of Trieste. Biol. Mar. Mediterr. 17 (1), 366-367.

Cabrini, M., Fornasaro, D., Cossarini, G., Lipizer, M., Virgilio, D., 2012. Phytoplankton temporal changes in a coastal northern Adriatic site during the last 25 years. Estuar. Coast. Shelf Sci. 115, 113-124. http://dx.doi.org/10.1016/j.ecss.2012.07.007.

Cabrini, M., Cerino, F., de Olazabal, A., et al., 2017. Potential transfer via ballast water of aquatic organisms with a particular focus to harmful and non-indigenous species: a survey from Adriatic ports. Mar. Pollut. Bull (in press).

Campanelli, A., Cabrini, M., Grilli, F., Fornasaro, D., Penna, P., Kljajić, Z., Marini, M., 2013. Physical, biochemical and biological characterization of two opposite areas in the southern Adriatic Sea (Mediterranean Sea). OJMS 3, 120-131. https://doi.org/ 
10.4236/ojms.2013.32013.

Carlton, J.T., 1996. Biological invasions and cryptogenic species. Ecology 77, 1653-1655. http://dx.doi.org/10.2307/2265767.

Caroppo, C., 2010. I Coccolitoforidi/Coccolithophorids. Biol. Mar. Mediterr. 17 (Suppl. 1), 690-693.

Caroppo, C., Fiocca, A., Sammarco, P., Magazzu, G., 1999a. Seasonal variations of nutrients and phytoplankton in the coastal SW Adriatic Sea (1995-1997). Bot. Mar. 42, 389-400. http://dx.doi.org/10.1515/BOT.1999.045.

Caroppo, C., Congestri, R., Bruno, M., 1999b. On the presence of Phalacroma rotundatum in the southern Adriatic Sea (Italy). Aquat. Microb. Ecol. 17, 301-310.

Caroppo, C., Congestri, R., Bruno, M., 2001. Dynamics of Dinophysis sensu lato species (Dinophyceae) in a coastal Mediterranean environment (Adriatic Sea). Cont. Shelf Res. 21, 1839-1854. http://dx.doi.org/10.1016/S0278-4343(01)00028-0.

Caroppo, C., Congestri, R., Bracchini, L., Albertano, P., 2005. On the presence of Pseudonitzschia calliantha Lundholm, Moestrup et Hasle and Pseudo-nitzschia delicatissima (Cleve) Heiden in the Southern Adriatic Sea (Mediterranean Sea, Italy). J. Plankton Res. 27, 763-774. http://dx.doi.org/10.1093/plankt/fbi050.

Ciminiello, P., Dell'Aversano, C., Fattorusso, E., Forino, M., Magno, G.S., Tartaglione, L., Quilliam, M.A., Tubaro, A., Poletti, R., 2005. Hydrophilic interaction liquid chromatography/mass spectrometry for determination of domoic acid in Adriatic shellfish. Rapid Commun. Mass Spectrom. 19, 2030-2038. http://dx.doi.org/10.1002/ rcm.2021.

Corriero, G., Pierri, C., Accoroni, S., et al., 2016. Ecosystem vulnerability to alien and invasive species: a case study on marine habitats along the Italian coast. Aquat. Conserv. 26, 392-409. http://dx.doi.org/10.1002/aqc.2550.

Cotterill, F.P.D., 1995. Systematics, biological knowledge and environmental conservation. Biodivers. Conserv. 4, 183-205. http://dx.doi.org/10.1007/BF00137784.

David, M., Gollasch, S., Leppäkoski, E., 2013. Risk assessment for exemptions from ballast water management - the Baltic Sea case study. Mar. Pollut. Bull. 75, 205-217. http:// dx.doi.org/10.1016/j.marpolbul.2013.07.031.

Davidson, K., Baker, K., Higgins, C., Higman, W., Swan, S., Veszelovski, A., Turner, A.D., 2015. Potential threats posed by new or emerging marine biotoxins in UK waters and examination of detection methodologies used for their control: cyclic imines. Mar. Drugs 13, 7087-7112. http://dx.doi.org/10.3390/md13127057.

Drakulović, D., Pestorić, B., Cvijan, M., Krivokapić, S., Vuksanović, N., 2012. Distribution of phytoplankton community in Kotor Bay (south-eastern Adriatic Sea). Cent. Eur. J. Biol. 7, 470-486. http://dx.doi.org/10.2478/s11535-012-0023-6.

Drakulović, D., Pestorić, B., Kraus, R., Ljubimir, S., Krivokapić, S., 2017. Phytoplankton community and trophic state in Boka Kotorska Bay. In: Joksimović, A., Djurović, M., Semenov, A.V., Zonn, I.S., Kostianoy, A.G. (Eds.), The Boka Kotorska Bay Environment. Springer International Publishing, Cham, pp. 169-201.

Editorial Board, 2015. Information System on Aquatic Non-Indigenous and Cryptogenic Species. (World Wide Web electronic publication. Version $2.36+$ ).

EFSA, 2008. Opinion of the scientific panel on contaminants in the food chain on a request from the European Commission on marine biotoxins in shellfish - yessotoxin group. EFSA J. 907, 1-62.

Fattorusso, E., Ciminiello, P., Costantino, V., Magno, S., Mangoni, A., Milandri, A., Poletti, R., Pompei, M., Viviani, R., 1992. Okadaic acid in mussels of Adriatic Sea. Mar. Pollut. Bull. 24, 234-237. http://dx.doi.org/10.3390/md10010140.

Fehling, J., Davidson, K., Bates, S.S., 2005. Growth dynamics of non-toxic Pseudo-nitzschia delicatissima and toxic $P$. seriata (Bacillariophyceae) under simulated spring and summer photoperiods. Harmful Algae 4, 763-769. http://dx.doi.org/10.1016/j.hal. 2004.11.002.

Feki-Sahnoun, W., Hamza, A., Njah, H., Barraj, N., Mahfoudi, M., Rebai, A., Hassen, M.B., 2017. A Bayesian network approach to determine environmental factors controlling Karenia selliformis occurrences and blooms in the Gulf of Gabès, Tunisia. Harmful Algae 63, 119-132. http://dx.doi.org/10.1016/j.hal.2017.01.013.

Francé, J., Mozetič, P., 2006. Ecological characterization of toxic phytoplankton species (Dinophysis spp., Dinophyceae) in Slovenian mariculture areas (Gulf of Trieste, Adriatic Sea) and the implications for monitoring. Mar. Pollut. Bull. 52, 1504-1516. http://dx.doi.org/10.1016/j.marpolbul.2006.05.012.

Fritz, L., Triemer, R.E., 1985. A rapid simple technique utilizing Calcofluor white M2R for the visualization of dinoflagellate thecal plates. J. Phycol. 21, 662-664.

Gallitelli, M., 2005. Respiratory illness as a reaction to tropical algal blooms occuring in a temperate climate. JAMA 293, 2599-2600. http://dx.doi.org/10.1001/jama.293.21. 2599-c.

Garaventa, F., Magaletti, E., Castriota, L., Silvestri, C., Tornambè, A., Falautano, M., Maggio, T., Gollasch, S., Muha, T.P., Mozetič, P., Pigozzi, S., David, M., 2014. Review and comment general categorization criteria and selection of a promising EWS approach for the Adriatic. In: BALMAS Project. WP 6.3, pp. 16.

Godrijan, J., Marić, D., Tomažić, I., Precali, R., Pfannkuchen, M., 2013. Seasonal phytoplankton dynamics in the coastal waters of the north-eastern Adriatic Sea. J. Sea Res. 77, 32-44. http://dx.doi.org/10.1016/j.seares.2012.09.009.

Gómez, F., 2003. Checklist of Mediterranean free-living dinoflagellates. Bot. Mar. 46, 215-242. http://dx.doi.org/10.1515/bot.2003.021.

Gómez, F., 2008. Phytoplankton invasions: comments on the validity of categorizing the non-indigenous dinoflagellates and diatoms in European seas. Mar. Pollut. Bull. 56, 620-628. http://dx.doi.org/10.1016/j.marpolbul.2007.12.014.

Gómez, F., 2010. Changes in the Mediterranean phytoplankton community related to climate warming. In: Briend, F. (Ed.), Phytoplankton Responses to Mediterranean Environmental Changes. CIESM Workshop Monographs 40. pp. 37-42 Monaco.

Grbin, D., Pfannkuchen, M., Babić, I., Mejdandžić, M., Mihanović, H., Marić Pfannkuchen, D., Godrijan, J., Peharec Štefanić, P., Olujić, G., Ljubešić, Z., 2017. Multigene phylogeny and morphology of newly isolated strain of Pseudo-nitzschia mannii Amato \& Montresor (Adriatic Sea). Diatom Res. 32, 127-131. https://doi.org/10.1080/ 0269249X.2017.1284158.
Guilloux, L., Rigaut-Jalabert, F., Jouenne, F., Ristori, S., Viprey, M., Not, F., Vaulot, D., Simon, N., 2013. An annotated checklist of marine phytoplankton taxa at the SOMLIT-Astan time series off Roscoff (Western English Channel, France): data collected from 2000 to 2010. Cah. Biol. Mar. 54, 247-256.

Guiry, M.D., Guiry, G.M., 2017. AlgaeBase. World-wide Electronic Publication. National University of Ireland, Galway. http://www.algaebase.org (searched on 13 October 2017).

Hallegraeff, G.M., 1993. A review of harmful algal blooms and their apparent global increase. Phycologia 32, 79-99. http://dx.doi.org/10.2216/i0031-8884-32-2-79.1.

Hallegraeff, G.M., Anderson, D.M., Cembella, A., 2004. Manual on Harmful Marine Microalgae. UNESCO Publishing, Paris.

Honsell, G., Poletti, R., Pompei, M., Sidari, L., Milandri, A., Casadei, C., Viviani, R., 1996. Alexandrium minutum Halim and PSP contamination in the Northern Adriatic Sea (Mediterranea Sea). In: Yasumoto, T., Oshima, Y., Fukuyo, Y. (Eds.), Harmful and Toxic Algal Blooms. Intergovernmental Oceanographic Commission of UNESCO, pp. $77-80$.

IMO, 2004. International Convention for the Control and Management of Ships' Ballast Water and Sediments. Adopted on 13 February 2004. International Maritime Organization, London, pp. 36.

Ingarao, C., Lanciani, G., Teodori, A., Pagliani, T., 2009. First presence of Ostreopsis cfr. ovata (Dinophyceae) along Abruzzo coasts (W Adriatic Sea). Biol. Mar. Mediterr. 16, 172-173.

John, U., Litaker, R.W., Montresor, M., Murray, S., Brosnahan, M.L., Anderson, D.M., 2014. Formal revision of the Alexandrium tamarense species complex (Dinophyceae) taxonomy: the introduction of five species with emphasis on molecular-based (rDNA) classification. Protist 165, 779-804. http://dx.doi.org/10.1016/j.protis.2014.10.001.

Jouenne, F., Lefebvre, S., Véron, S., Lagadeuc, Y., 2007. Phytoplankton community structure and primary production in small intertidal estuarine-bay ecosystem (Eastern English Channel, France). Mar. Biol. 151, 805-825. http://dx.doi.org/10 1007/s00227-006-0440-Z.

Juliano, V.B., Garcia, V.M.T., 2006. Cysts of potentially harmful dinoflagellates, with emphasis on the genus Alexandrium, in Sepetiba Bay (Brazil) during a port survey of GloBallast. Afr. J. Mar. Sci. 28, 299-303. https://doi.org/10.2989/ 18142320609504166.

Kilroy, C., Unwin, M., 2011. The arrival and spread of the bloom-forming, freshwater diatom, Didymosphenia geminata, in New Zealand. Aquat. Invasions 6, 249-262. http://dx.doi.org/10.3391/ai.2011.6.3.02.

Krammer, K., Lange-Bertalot, H., 1995. Süßwasserflora von Mitteleuropa: Bacillariophyceae. 1. Teil: Naviculaceae. Süßwasserflora von Mitteleuropa - Band 2/ 1. VEB Gustav Fischer Verlag, Jena, Stuttgart.

Kraus, R., Supić, N., 2011. Impact of circulation on high phytoplankton blooms and fish catch in the northern Adriatic (1990-2004). Estuar. Coast. Shelf Sci. 91, 198-210. http://dx.doi.org/10.1016/j.ecss.2010.10.021.

Kraus, R., Supić, N., Precali, R., 2016. Factors favouring large organic production in the northern Adriatic: towards the northern Adriatic empirical ecological model. Ocean Sci. 12, 19-37. http://dx.doi.org/10.5194/os-12-19-2016.

Lassus, P., Chomérat, N., Hess, P., Nézan, E., 2016. Toxic and Harmful Microalgae of the World Ocean/Micro-algues toxiques et nuisibles de l'océan mondial. IOC Manuals and Guides 68 International Society for the Study of Harmful Algae/Intergovernmental Oceanographic Commission of UNESCO, Denmark.

Ljubešić, Z., Bosak, S., Viličić, D., Borojević, K.K., Marić, D., Godrijan, J., Ujević, I., Peharec, P., Đakovac, T., 2011. Ecology and taxonomy of potentially toxic Pseudonitzschia species in Lim Bay (north-eastern Adriatic Sea). Harmful Algae 10, 713-722. http://dx.doi.org/10.1016/j.hal.2011.06.002.

Lugliè, A., Giacobbe, M.G., Sannio, A., Fiocca, F., Sechi, N., 2003. First record of the dinoflagellate Alexandrium catenella (Dinophyta), a potential producer of paralytic shellfish poisoning. In: Italian Waters (Sardinia, Tyrrhenian Sea). Bocconea 16. pp 1045-1051.

Mangialajo, L., Ganzin, N., Accoroni, S., et al., 2011. Trends in Ostreopsis proliferation along the Northern Mediterranean coasts. Toxicon 57, 408-420. http://dx.doi.org/ 10.1016/j.toxicon.2010.11.019.

Mangoni, O., Modigh, M., Mozetič, P., Bergamasco, A., Rivaro, P., Saggiomo, V., 2008. Structure and photosynthetic properties of phytoplankton assemblages in a highly dynamic system, the Northern Adriatic Sea. Estuar. Coast. Shelf Sci. 77, 633-644. http://dx.doi.org/10.1016/j.ecss.2007.10.023.

Marangoni, C., Pienaar, R.N., Sym, S.D., 2001. Possible introduction of alien phytoplankton via shipping ballast water: a South African perspective. S. Afr. J. Bot. 67, 465-474. http://dx.doi.org/10.1016/S0254-6299(15)31165-0.

Marasović, I., Ninčević-Gladan, Ž., Skejić, S., Grbec, B., Bužančić, M., Ujević, I., 2007. Temporal distribution of Dinophysis spp. in relation to diarrhetic shellfish poisoning shellfish toxicity. Int. J. Environ. Health 1, 493-506.

Marić, D., Ljubešić, Z., Godrijan, J., Viličić, D., Ujević, I., Precali, R., 2011. Blooms of the potentially toxic diatom Pseudo-nitzschia calliantha Lundholm, Moestrup \& Hasle in coastal waters of the northern Adriatic Sea (Croatia). Estuar. Coast. Shelf Sci. 92, 323-331. http://dx.doi.org/10.1016/j.ecss.2011.01.002.

Marić, D., Kraus, R., Godrijan, J., Supić, N., Djakovac, T., Precali, R., 2012. Phytoplankton response to climatic and anthropogenic influences in the north-eastern Adriatic during the last four decades. Estuar. Coast. Shelf Sci. 115, 98-112. http://dx.doi.org/ 10.1016/j.ecss.2012.02.003.

Milandri, A., Pompei, M., Poletti, R., 2005. Fioriture tossiche in Emilia Romagna e attività del centro nazionale di riferimento per le biotossine marine. In: Mattei, D., Melchiorre, S., Messineo, V., Bruno, M. (Eds.), Toxic Algal Blooms in Italy: Risk Assessment and Epidemiology. Rapporti ISTISAN 05/29. Tipografia Facciotti, Roma, Italy, pp. 123-129.

Moestrup, Ø., Akselman, R., Cronberg, G., Elbraechter, M., Fraga, S., Halim, Y., Hansen, G., Hoppenrath, M., Larsen, J., Lundholm, N., Nguyen, L.N., Zingone, A., 2009. IOC- 
UNESCO Taxonomic Reference List of Harmful Micro Algae. onwards. (Accessed at http://www.marinespecies.org/hab on 2017-05-16).

Moscatello, S., Caroppo, C., Hajdëri, E., Belmonte, G., 2011. Space distribution of phytoand microzooplankton in the Vlora Bay (Southern Albania, Mediterranean Sea). J. Coast. Res. 10058, 80-94. http://www.bioone.org/doi/full/10.2112/SI_58_8.

Moschandreou, K.K., Nikolaidis, G., 2010. The genus Pseudo-nitzschia (Bacillariophyceae) in Greek coastal waters. Bot. Mar. 53, 159-172.

Mozetič, P., Francé, J., Kogovšek, T., Talaber, I., Malej, A., 2012. Plankton trends and community changes in a coastal sea (northern Adriatic): bottom-up vs. top-down control in relation to environmental drivers. Estuar. Coast. Shelf Sci. 115, 138-148. http://dx.doi.org/10.1016/j.ecss.2012.02.009.

Ninčević Gladan, Ž., Skejić, S., Bužančić, M., Marasović, I., Arapov, J., Ujević, I., Bojanić, N., Grbec, B., Kušpilić, G., Vidjak, O., 2008. Seasonal variability in Dinophysis spp. abundances and diarrhetic shellfish poisoning outbreaks along the eastern Adriatic coast. Bot. Mar. 51, 449-463. http://dx.doi.org/10.1515/BOT.2008.067.

Ninčević Gladan, Ž., Marasović, I., Grbec, B., Skejić, S., Bužančić, M., Kušpilić, G., Matijević, S., Matić, F., 2010a. Inter-decadal variability in phytoplankton community in the Middle Adriatic (Kaštela Bay) in relation to the North Atlantic Oscillation. Estuar. Coast. 33, 376-383. http://dx.doi.org/10.1007/s12237-009-9223-3.

Ninčević Gladan, Ž., Ujević, I., Milandri, A., Marasović, I., Ceredi, A., Pigozzi, S., Arapov, J., Skejić, S., Orhanović, S., Isajlović, I., 2010b. Is yessotoxin the main phycotoxin in Croatian waters? Mar. Drugs 8, 460-470. http://dx.doi.org/10.3390/md8030460.

Ninčević Gladan, Z., Ujević, I., Milandri, A., Marasović, I., Ceredi, A., Pigozzi, S., Arapov, J., Skejić, S., 2011. Lipophilic toxin profile in Mytilus galloprovincialis during episodes of Diarrhetic Shellfish Poisoning (DSP) in the N.E. Adriatic Sea in 2006. Molecules 16, 888-899. http://dx.doi.org/10.3390/molecules16010888.

Ninčević Gladan, Ž., Arapov, J., Casabianca, S., Penna, A., Honsell, G., Brovedani, V., Pelin, M., Tartaglione, L., Dell'Aversano, C., Tubaro, A., Skejić, S., Bužančić, M., Bakrač, A., 2016. Massive occurence of benthic dinoflagellates Ostreopsis cf. ovata and Coolia monotis in the eastern Adriatic Sea. In: The 17th International Conference on Harmful Algae, Florianópolis, Santa Catarina, Brasil, pp. 177.

de Nooy, W., Mrvar, A., Batagelj, V., 2011. Exploratory Social Network Analysis with Pajek. Cambridge University Press, New York, NY, USA.

Olenin, S., Alemany, F., Cardoso, A.C., Gollasch, S., Goulletquer, P., Lehtiniemi, M., McCollin, T., Minchin, D., Miossec, L., Occhipinti Ambrogi, A., Ojaveer, H., Jensen, K., Stankiewicz, M., Wallentinus, I., Aleksandrov, B., 2010. Marine Strategy Framework Directive. Task Group 2 Report. Non-indigenous Species. International Council for the Exploration of the Sea.

Penko, L., Zupančič, G., Kocijančič, U., Popit, A., Gorišek, M., Aubreht, A., Forte, C., Magaletti, E., Marini, M., Grilli, F., Bastianini, M., Ninčević Gladan, Ž., Zec, D., Joksimović, D., Markovčič Kostelac, M., Vidas, S., 2016. Integrated Operational Plan for Ballast Water Management in the Adriatic. Institute for Water of the Republic of Slovenia, Ljubljana.

Penna, A., Fraga, S., Battocchi, C., Casabianca, S., Giacobbe, M.G., Riob, xf, Pilar, Vernesi, C., Maggs, C., 2010. A phylogeographical study of the toxic benthic dinoflagellate genus Ostreopsis Schmidt. J. Biogeogr. 37, 830-841. http://dx.doi.org/10.1111/j. 1365-2699.2009.02265.x.

Penna, A., Fraga, S., Battocchi, C., Casabianca, S., Perini, F., Capellacci, S., Casabianca, A., Riobó, P., Giacobbe, M.G., Totti, C., Accoroni, S., Vila, M., Reñé, A., Scardi, M., Aligizaki, K., Nguyen-Ngoc, L., Vernesi, C., 2012. Genetic diversity of the genus Ostreopsis Schmidt: phylogeographical considerations and molecular methodology applications for field detection in the Mediterranean Sea. Cryptogam. Algol. 33, 153-163. http://dx.doi.org/10.7872/crya.v33.iss2.2011.153.

Pfannkuchen, M., Godrijan, J., Marić Pfannkuchen, D., Iveša, L., Kružić, P., Ciminiello, P., Dell'Aversano, C., Dello Iacovo, E., Fattorusso, E., Forino, M., Tartaglione, L., Godrijan, M., 2012. Toxin-producing Ostreopsis cf. ovata are likely to bloom undetected along coastal areas. Environ. Sci. Technol. 46, 5574-5582. http://dx.doi. org/10.1021/es300189h.

Pistocchi, R., Guerrini, F., Pezzolesi, L., Riccardi, M., Vanucci, S., Ciminiello, P., Dell'Aversano, C., Forino, M., Fattorusso, E., Tartaglione, L., Milandri, A., Pompei, M., Cangini, M., Pigozzi, S., Riccardi, E., 2012. Toxin levels and profiles in microalgae from the north-western Adriatic Sea-15 years of studies on cultured species. Mar. Drugs 10, 140-162. http://dx.doi.org/10.3390/md10010140.

Pyšek, P., Hulme, P.E., Nentwig, W., 2009. Glossary of the main technical terms used in the handbook. In: DAISIE (Ed.), Handbook of Alien Species in Europe. Springer, Berlin, pp. 375-379.

Rampi, L., Bernhard, M., 1980. Chiave per la determinazione delle peridinee pelagiche mediterranee. C.N.E.N. (RT/B10(80)8), Roma.

Salas, R., Tillmann, U., John, U., Kilcoyne, J., Burson, A., Cantwell, C., Hess, P., Jauffrais, T., Silke, J., 2011. The role of Azadinium spinosum (Dinophyceae) in the production of azaspiracid shellfish poisoning in mussels. Harmful Algae 10, 774-783. http://dx.doi. org/10.1016/j.hal.2011.06.010.

Saracino, O.D., Rubino, F., 2006. Phytoplankton composition and distribution along the
Albanian coast, South Adriatic Sea. Nova Hedwigia 83, 253-266. http://dx.doi.org/ 10.1127/0029-5035/2006/0083-0253.

Sedmak, B., Fanuko, N., 1991. Occurrence of Dinophysis spp. and toxic shellfish in the Northern Adriatic. J. Appl. Phycol. 3, 289-294. http://dx.doi.org/10.1007/ BF00026090.

Socal, G., Pugnetti, A., Alberighi, L., Acri, F., 2002. Observations on phytoplankton productivity in relation to hydrography in the northern Adriatic. Chem. Ecol. 18, 61-73. https://doi.org/10.1080/02757540212686.

Spaulding, S.A., Elwell, L., 2007. Increase in nuisance blooms and geographic expansion of the freshwater diatom Didymosphenia geminata. In: U.S. Geological Survey OpenFile Report 2007-1425, pp. 38.

Streftaris, N., Zenetos, A., 2006. Alien marine species in the Mediterranean - the 100 'worst invasives' and their impact. Mediterr. Mar. Sci. 7, 87-118.

Streftaris, N., Zenetos, A., Papathanassiou, E., 2005. Globalisation in marine ecosystems: the story of non-indigenous marine species across European seas. Oceanogr. Mar. Biol. Annu. Rev. 43, 419-453.

Sutherland, T.F., Leonard, C., Taylor, F.J.R., 1992. A segmented pipe sampler for integrated profiling of the upper water column. J. Plankton Res. 14, 915-923. http:// dx.doi.org/10.1093/plankt/14.7.915.

Throndsen, J., 1978. Preservation and storage. In: Sournia, A. (Ed.), Phytoplankton Manual. UNESCO, Paris, pp. 69-74.

Totti, C., Civitarese, G., Acri, F., Barletta, D., Candelari, G., Paschini, E., Solazzi, A., 2000. Seasonal variability of phytoplankton populations in the middle Adriatic sub-basin. J. Plankton Res. 22, 1735-1756. http://dx.doi.org/10.1093/plankt/22.9.1735.

Totti, C., Accoroni, S., Cerino, F., Cucchiari, E., Romagnoli, T., 2010. Ostreopsis ovata bloom along the Conero Riviera (northern Adriatic Sea): relationships with environmental conditions and substrata. Harmful Algae 9, 233-239. http://dx.doi.org/ 10.1016/j.hal.2009.10.006.

Trainer, V.L., Wells, M.L., Cochlan, W.P., Trick, C.G., Bill, B.D., Baugh, K.A., Beall, B.F., Herndon, J., Lundholmf, N., 2009. An ecological study of a massive bloom of toxigenic Pseudo-nitzschia cuspidata off the Washington State coast. Limnol. Oceanogr. 54, 1461-1474. http://dx.doi.org/10.4319/lo.2009.54.5.1461.

Trainer, V.L., Bates, S.S., Lundholm, N., Thessen, A.E., Cochlan, W.P., Adams, N.G., Trick, C.G., 2012. Pseudo-nitzschia physiological ecology, phylogeny, toxicity, monitoring and impacts on ecosystem health. Harmful Algae 14, 271-300. http://dx.doi.org/10. 1016/j.hal.2011.10.025.

Ujević, I., Ninčević-Gladan, Ž., Roje, R., Skejić, S., Arapov, J., Marasović, I., 2010. Domoic acid - a new toxin in the Croatian Adriatic shellfish toxin profile. Molecules 15 , 6835-6849. http://dx.doi.org/10.3390/molecules15106835.

Ujević, I., Roje, R., Ninčević-Gladan, Ž., Marasović, I., 2012. First report of Paralytic Shellfish Poisoning (PSP) in mussels (Mytilus galloprovincialis) from eastern Adriatic Sea (Croatia). Food Control 25, 285-291. http://dx.doi.org/10.1016/j.foodcont. 2011.10.050.

Utermöhl, H., 1958. Zur Vervollkommung der Quantitativen Phytoplankton-Metodik. Mit. Int. Verein. Theor. Angew. Limnol. 9, 1-38.

Vila, M., Garcés, E., Maso, M., Camp, J., 2001. Is the distribution of the toxic dinoflagellate Alexandrium catenella expanding along the NW Mediterranean coast? Mar. Ecol. Prog. Ser. 222, 73-83. http://dx.doi.org/10.3354/meps222073.

Viličić, D., Marasović, I., Mioković, D., 2002. Checklist of phytoplankton in the eastern Adriatic Sea. Acta Bot. Croat. 61, 57-91.

Viličić, D., Djakovac, T., Burić, Z., Bosak, S., 2009. Composition and annual cycle of phytoplankton assemblages in the northeastern Adriatic Sea. Bot. Mar. 52, 291-305. http://dx.doi.org/10.1515/BOT.2009.004.

Vlamis, A., Katkou, P., Rodriguez, I., Rey, V., Alfonso, A., Papazachariou, A., Zacharaki, T., Botana, A.M., Botana, L.M., 2015. First detection of tetrodotoxin in Greek shellfish by UPLC-MS/MS potentially linked to the presence of the dinoflagellate Prorocentrum minimum. Toxins 7, 1779-1807. http://dx.doi.org/10.3390/toxins7051779.

Zavatarelli, M., Pinardi, N., 2003. The Adriatic Sea modelling system: a nested approach. Ann. Geophys. 21, 345-364. http://dx.doi.org/10.5194/angeo-21-345-2003.

Zingone, A., 2015. Evaluation on the NIS from the Assessment Areas Ionian Sea and Western Mediterranean Sea. (Expert evaluation MFSD_NIS_1. 27 March 2013, updated March 2015).

Zingone, A., Licandro, P., Sarno, D., 2003. Revising paradigms and myths of phytoplankton ecology using biological time series. In: Briand, F. (Ed.), Mediterranean Biological Time Series. CIESM Workshop Monographs No. 22pp. 109-114 Monaco.

Zingone, A., Siano, R., D'Alelio, D., Sarno, D., 2006. Potentially toxic and harmful microalgae from coastal waters of the Campania region (Tyrrhenian Sea, Mediterranean Sea). Harmful Algae 5, 321-337. http://dx.doi.org/10.1016/j.hal.2005.09.002.

Zingone, A., Totti, C., Sarno, D., Cabrini, M., Caroppo, C., Giacobbe, M.G., Lugliè, A., Nuccio, C., Socal, G., 2010. Fitoplancton: metodiche di analisi quali-quantitativa. In: Socal, G., Buttino, I., Cabrini, M., Mangoni, O., Penna, A., Totti, C. (Eds.), Metodologie di studio del plancton marino. Manuali e Linee Guida 56/2010. ISPRA SIBM, pp. 213-237. 